\title{
Hydrocarbon habitat in the Zielin Late Permian isolated carbonate platform, western Poland
}

\author{
Zbigniew Mikołajewski ${ }^{1}$ Cezary Grelowski ${ }^{1} \cdot$ Krzysztof Kwolek $^{1} \cdot$ Franciszek Czechowski $^{2}$. \\ Mirosław Słowakiewicz ${ }^{3,4}$ (D) Irena Matyasik ${ }^{5} \cdot$ Izabella Grotek $^{4}$
}

Received: 21 August 2018 / Accepted: 25 November 2018 / Published online: 10 December 2018

(c) The Author(s) 2018

\begin{abstract}
In the Zielin oilfield in the Polish part of the Southern Permian Basin, oil and gas are produced from an Upper Permian Main Dolomite (Ca2) isolated platform. The paleohigh developed on a volcanic cone formed in Early Rotliegend time. Based on microfacies analysis of $\mathrm{Ca} 2$ reservoir rocks from four wells (Zielin-1, $-2,-3$ and $-3 \mathrm{KBis}$ ), four microfacies types are distinguished: peloidal dolomitized wackestone, intraclastic dolomitized rudstone and floatstone, biogenic boundstone, and intraclastic-bioclastic dolomitized packstone. In view of the lack of source rocks on the Zielin paleohigh revealed by Rock-Eval analyses, this isolated carbonate platform is regarded as a reservoir for migrating hydrocarbons. Biomarker analyses of two crude oils and nine carbonate rocks from the Zielin isolated carbonate platform and five crude oils from surrounding wells of the nearest Gorzów, Cychry, and Namyślin platforms indicate an origin for the oils from oil-prone type II kerogen, sourced from organic matter deposited under anoxic/suboxic conditions in a carbonate environment. Compared to organic matter extracted from the rock samples, oils from the Zielin-2 and 3KBis wells are characterized by higher values of the pristane/ phytane (Pr/Ph) and dibenzothiophene/phenanthrene (DBT/P) ratios, lower relative concentrations of polyalkylaromatics, as well as a higher maturity evaluated from the methylphenanthrene (MPI-1) and methyldibenzothiophene (MDR) indices. The molecular composition of sesquiterpanes, $n$-alkylbenzenes, and polyalkylnaphthalenes revealed a diverse specificity within the oils analyzed and allowed their separation into two groups. Oils Różańsko-4, Zielin-2, Zielin-3KBis, and Namyślin-1 represent group I, whereas Barnówko-3, Mostno-2 and Cychry-2 group II. From the gradient direction in the $n$-decane/ naphthalene ratio and maturity for respective crude oils belonging to group I, it is concluded that the oils accumulated in the Zielin atoll migrated from NW to SE following subsidence and tilting of the platform in this part of the Main Dolomite basin.
\end{abstract}

Keywords Zechstein Main Dolomite carbonate rocks · Off-platform highs · Hydrocarbons · Biomarkers · Maturity · Migration

Cezary Grelowski: Deceased.

Zbigniew Mikołajewski

zbigniew.mikolajewski@pgnig.pl

1 Polish Oil and Gas Company, Zielona Góra Branch, Pl. Staszica 9, 64-920 Piła, Poland

2 Institute of Geological Sciences, University of Wrocław, Pl. Maksa Borna 9, 50-204 Wrocław, Poland

3 Faculty of Geology, University of Warsaw, ul. Żwirki i Wigury 93, 02-089 Warsaw, Poland

4 Polish Geological Institute, ul. Rakowiecka 4, 00-975 Warsaw, Poland

5 Oil and Gas Institute, ul. Lubicz 25A, 31-503 Kraków, Poland

\section{Introduction}

Off-platform carbonate highs refer to shallow-water isolated carbonate accumulations (islands, isolated platforms) and are well-known targets for hydrocarbon exploration in frontier and mature basins. Most off-platform highs or buildups have steep margins and slopes, subjected to different wave and storm regimes, and platform interiors which comprise sand bodies, sandy muds and muds, and microbial communities, which produce distinctive facies patterns (Tucker and Wright 1990; Wright and Burchette 1996; Bosence 2005).

An isolated carbonate paleohigh related to a sulphate platform on a submerged volcanic cone is located in the subsurface in the eastern part of the Southern Permian Basin (SPB) at Zielin in western Poland (Fig. 1). A seismic survey 

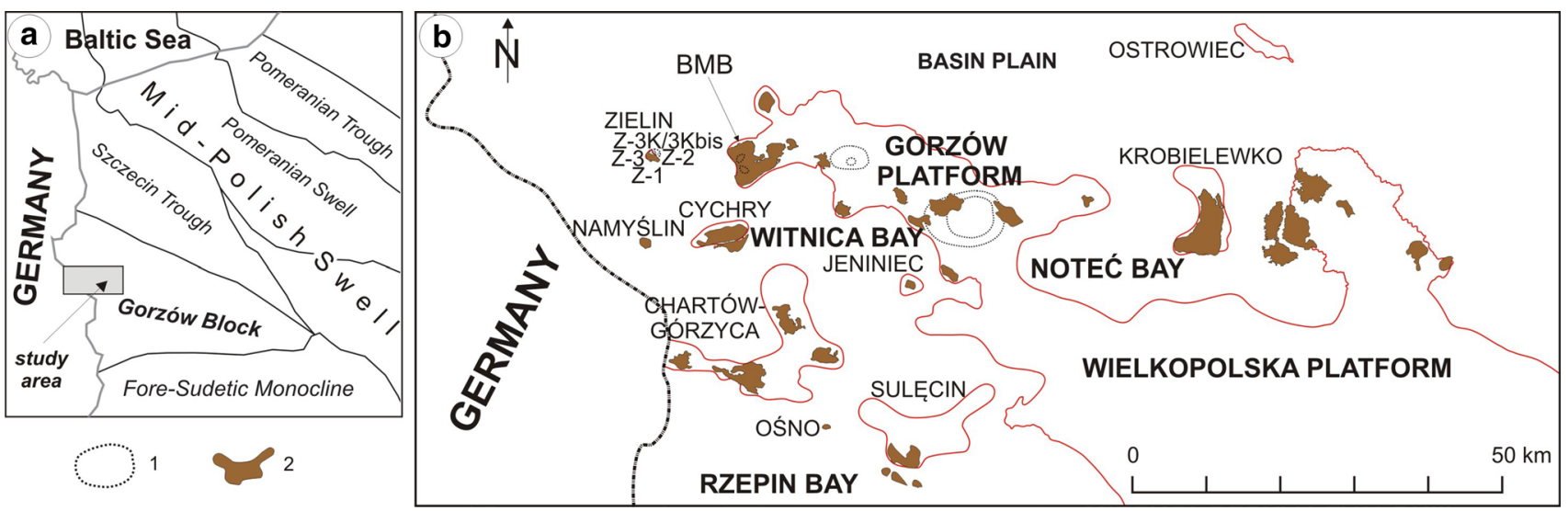

Fig. 1 Geological regional subdivision of NW Poland at the subCenozoic paleosurface (a, Narkiewicz and Dadlez 2008), and b the study area showing extent (red line, after Wagner 2012) of Main Dolomite carbonate platforms. Cychry, Chartów-Górzyca, Jeniniec, Krobielewko, Namyślin, Ostrowiec, Ośno, Sulęcin and Zielin are iso-

was undertaken here in 1997. The first Zielin-1 well was drilled in 1992, which discovered the Zielin oil and gas field (Oświęcimska and Protas 1995; Czekański et al. 2010). The field is located ca. $10 \mathrm{~km}$ to the west of Barnówko-MostnoBuszewo (BMB), the largest oilfield in Poland (Mamczur et al. 1997). The Zielin isolated carbonate platform is composed of evaporite-carbonate successions of the Polish Zechstein 1 (PZ1, Werra) and 2 (PZ2, Stassfurt) cycles (Fig. 2). The platform forms a stratigraphic trap for hydrocarbons, which

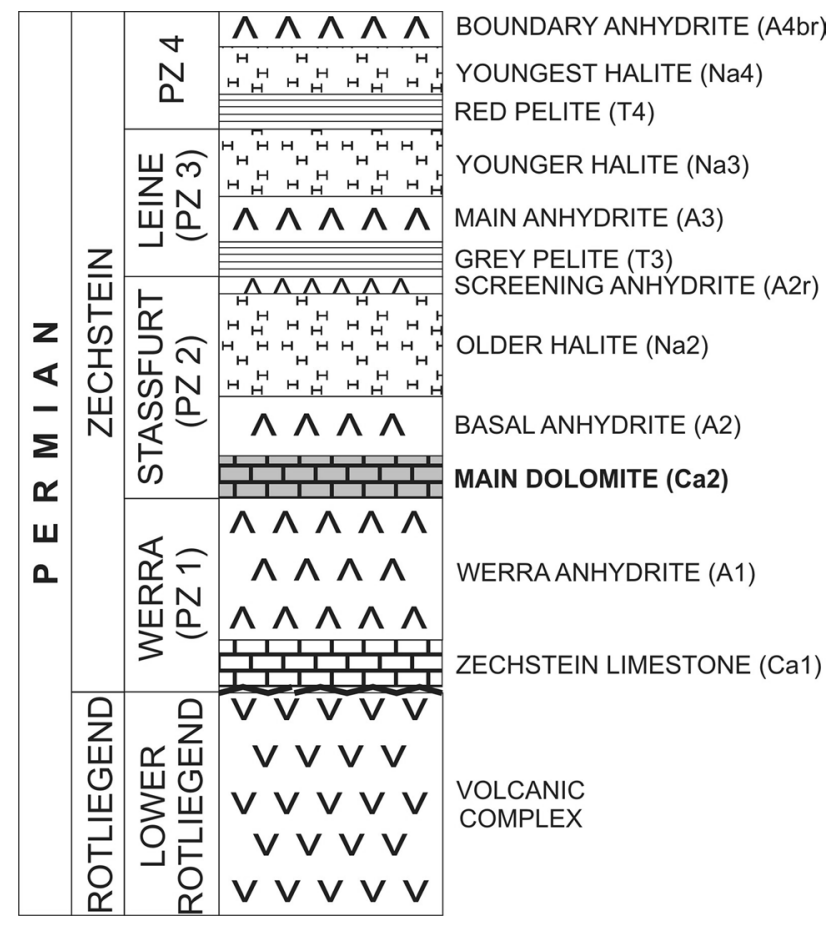

Fig. 2 Permian lithostratigraphy in the Zielin area. PZ4 = Leine + Ohre cycles. Wavy line - unconformity lated carbonate platforms or off-platform highs (Jeniniec, Namyślin, Ostrowiec, Ośno). 1. Supposed chain of Lower Rotliegend paleovolcanoes interpreted from various $3 \mathrm{D}$ seismic surveys; 2 . Ca2 petroleum accumulations; $B M B$ Barnówko-Mostno-Buszewo field; Z-1, Z-2, Z-3, Z-3 K/3 Kbis are Zielin wells

occur in the Zechstein Main Dolomite (Ca2) carbonate rocks, a widespread reservoir interval in Poland. In the Zielin field, oil initially in-place is about $5 \mathrm{MBBL}$ with about $19.6 \mathrm{BCF}$ of gas. Production began in the early 1990's and two-thirds of the initial reserves have already been exploited. This paper documents the relationship between isolated paleohigh development and formation of the Zielin hydrocarbon accumulation. Despite recent progress in the evaluation of petroleum systems in the Ca2 unit in Poland (Kotarba and Wagner 2007; Kosakowski and Krajewski 2014, 2015), geochemical data on local oilfields remains scarce. In the present study, molecular indicators for organic input and depositional environment are used to re-evaluate oil-oil and oil-source rock relationships to identify their genetic origin within the Zielin field area. Particular attention is paid to the origin of the hydrocarbons and whether they migrated to the carbonate reservoir rocks from $\mathrm{Ca} 2$ shallow-basin facies or were generated in situ.

\section{Geological background and Permian lithostratigraphy}

The isolated platform at Zielin is located in the western part of the Gorzów Block (Fig. 1a), a region in which several larger isolated carbonate platforms are known to occur (Peryt and Dyjaczyński 1991; Kotarba and Wagner 2007; Fig. 1b). Similar off-platform Ca2 carbonate highs are also located in NE Germany (Strohmenger et al. 1993) and developed in Zechstein cycle 1 (PZ1) on Lower Rotliegend paleohighs (Kiersnowski et al. 2010) built of volcanic rocks (Geißler et al. 2008; Breitkreuz et al. 2008; Maliszewska et al. 2016) or Lower Carboniferous rocks. In the Zielin area, Zechstein rocks lie unconformably on Lower Rotliegend lava shields and volcanic cones, 
probably forming a chain of paleo-volcanoes $(\mathrm{H}$. Kiersnowski-pers. com.) not completely eroded before the Zechstein transgression. Volcanic rocks are represented by dacite, andesite, basalt and trachyte, known elsewhere in the SPB (Figs. 1, 2; Breitkreuz et al. 2008; Maliszewska et al. 2016). Late Carboniferous-Early Permian volcanic rocks (interbedded with epiclastic deposits) are $\sim 400 \mathrm{~m}$ thick to the east and $>1600 \mathrm{~m}$ thick to the south of Zielin, respectively, and overlie an eroded Lower Carboniferous substratum. Upper Rotliegend sedimentary rocks are minor or absent (Peryt and Dyjaczyński 1991; Maliszewska et al. 2003). Zechstein sulphate platforms formed flat surfaces with a positive relief from shallow-water deposition. The PZ1 cycle consists of a thin Zechstein Limestone (Ca1) carbonate basinal facies and thick Werra Anhydrite (A1 = Lower Anhydrite [A1d] + Upper Anhydrite [A1 g]) evaporites. Oldest Halite (Na1) rock salts, separating A1d from A1 g, are absent. The PZ1 cycle is overlain by $\mathrm{Ca} 2$ carbonate and basal anhydrite (A2) evaporite rocks belonging to the Zechstein 2 cycle (PZ2) (Fig. 2).

\section{Materials and methods}

\section{Materials}

For sedimentological and petrographic analyses, the available $\mathrm{Ca} 2$ cores from Zielin-1, -2, -3, and 3KBis wells (a total of approximately $53.6 \mathrm{~m}$ of the core; location of wells is indicated in Fig. 1b) were studied. All cores were cut perpendicular to bedding planes using a water-cooled saw. Polished slabs were logged in detail at a macroscale at the Borehole Core Storage of the Polish Oil and Gas Company (PGNiG SA) in Piła and documented by digital photography. Samples for microfacies analysis were collected from the cores at ca. 1-m intervals.

\section{Petrophysical analysis}

Forty-six $\mathrm{Ca} 2$ core plugs were used to determine porosity and permeability values (Fig. 3). Porosity values were obtained with a helium porosimeter based on Boyle's law whereas permeability values were achieved from a nitrogen permeameter and calculated according to the Kozeny-Carman equation

\section{D seismic survey}

High-resolution 3D seismic reflection data were obtained by Geofizyka Toruń in 1997 for PGNiG SA and were acquired for the purpose of this study. Seismic profiles in the study area were oriented north-south and east-west. The data were evaluated by means of 3D SuperSeisWorks software (Landmark Graphics).

\section{Reflected light microscopy}

Four samples were microscopically studied in reflected $(\lambda=546 \mathrm{~nm})$ monochromatic green light and fluorescent light (UV) to identify macerals from the liptinite group and bituminous impregnations, following procedures described by Taylor et al. (1998). Analyses were carried out on a polarizing Axio Imager Zeiss microscope equipped with a reflectivity photometer PMT 200 to measure OM reflectance. The measurements were performed in immersion oil $\left(n_{\mathrm{D}}=1.515\right)$ at $20-25{ }^{\circ} \mathrm{C}$ on polished core sections containing vitrinite macerals or vitrinite-like material. Mean random light reflectance of these components shows a direct relationship with thermal maturity of OM in sediments. The measurements were performed on grains $>5 \mu \mathrm{m}$ in diameter and optic glass of known reflectance $(0.595,0.907$, and $1.722 \%)$ were used as standards. Quantitative analysis was done by the planimetry method at the micrometer screw gauge resolution of $0.2 \mathrm{~mm}$. The nomenclature and classification adopted by the International Committee for Petrology of Coal (ICCP) were used to describe the organic components. For samples in which there was no vitrinite, the calculated reflectance of vitrinite was based on the mean random reflectivity value of the solid bitumen (BRr) according to the formula developed by Schoenherr et al. (2007):

$\left.\mathrm{VR}_{\mathrm{r}}=\left(\mathrm{BR}_{\mathrm{r}}+0.2443\right) / 1.0495\right)$.

Peak paleotemperature was calculated from vitrinite reflectance using the equation evaluated experimentally by Barker and Pawlewicz (1994):

$T_{\text {peak }}=\left(\operatorname{lnVR}_{\mathrm{r}}+1.68\right) / 0.0124$.

\section{Rock-Eval pyrolysis}

Assessment of source rock potential, quality, and hydrocarbon thermal maturity were determined using a Rock-Eval 6 pyrolysis apparatus. Analyses were performed on 27 cores from Zielin-1, -2, and -3KBis wells (see Table 2). Samples preliminarily water-washed and dried at room temperature were pulverized to particles $<2 \mathrm{~mm}$. Measurements were performed on $45-80 \mathrm{mg}$ sample mass and preceded by two heating cycles in Basic Mode. In the first cycle, the sample was placed in a pyrolytic oven and heated up to $650{ }^{\circ} \mathrm{C}$ in a helium atmosphere. The content of free volatile hydrocarbons released during the isothermal temperature step at $300{ }^{\circ} \mathrm{C}$ measured by the flame-ionization detector was recorded as peak $S_{1}$. In a further phase of this cycle 


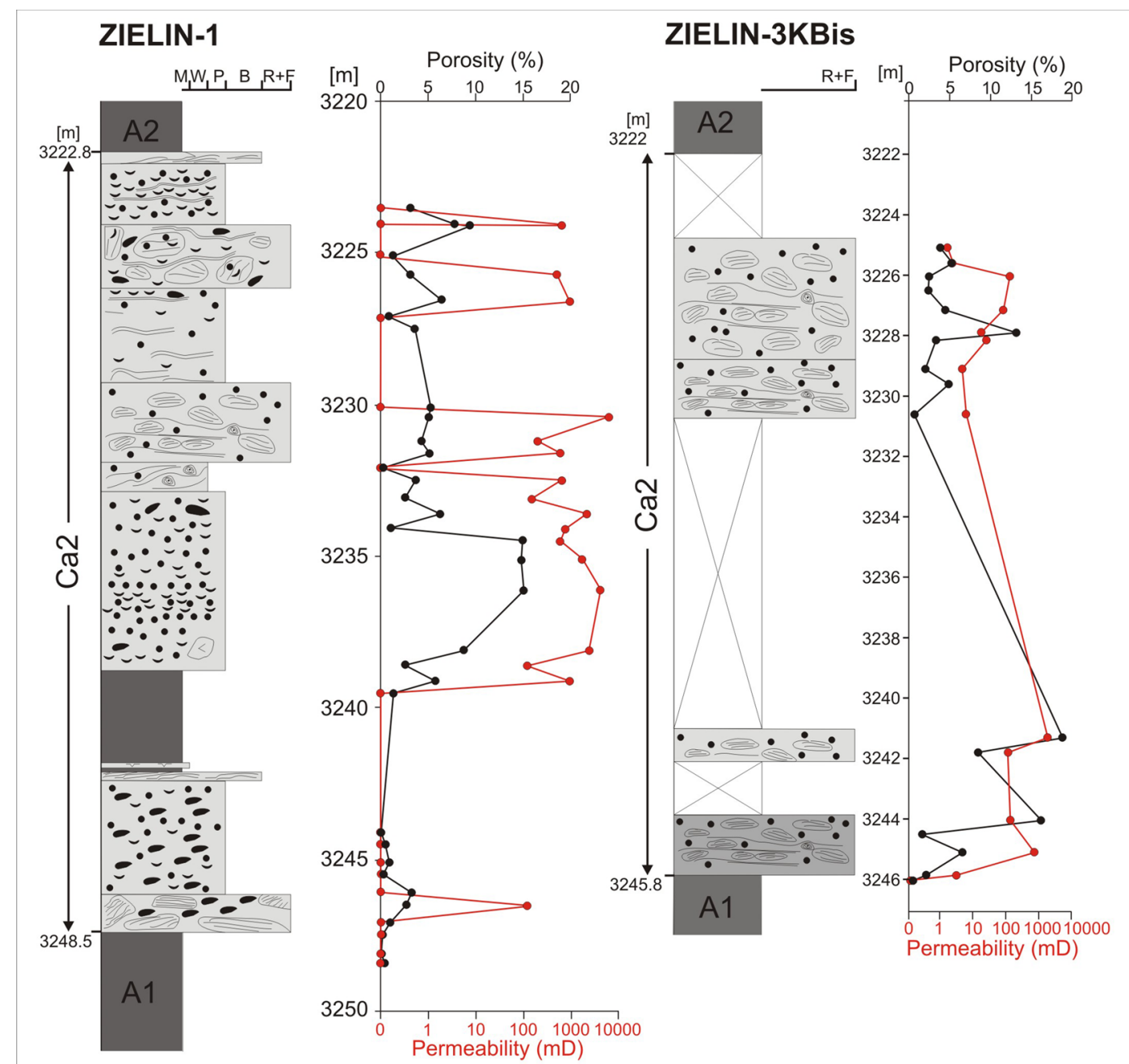

\section{ZIELIN-2}

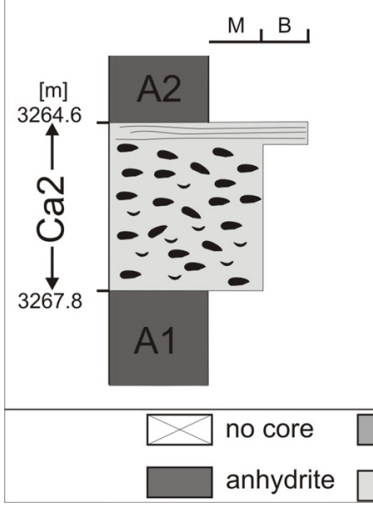

ZIELIN-3
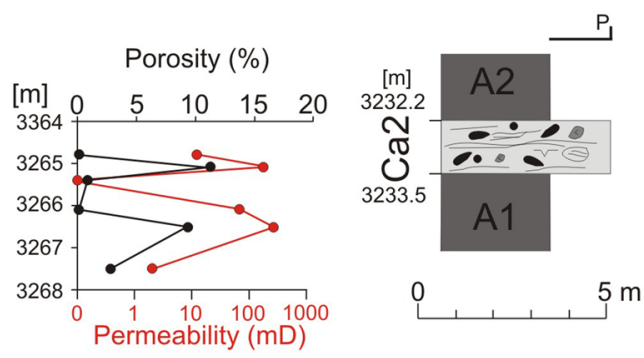

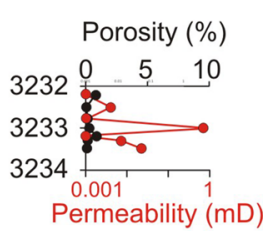

$\mathrm{m}$

\begin{tabular}{|c|c|c|c|c|c|c|}
\hline limestone & (2) (2) & ooids and oncoids & $\bullet \bullet$ & peloids & $\equiv$ & biolaminae \\
\hline dolo & 50 & intraclasts & こぇ & bioclasts & $\checkmark v$ & shrinkage cracks \\
\hline
\end{tabular}

Fig. 3 Lithological logs, porosity and permeability through the Zechstein Main Dolomite (Ca2) carbonate rocks in the Zielin-1, -2, -3 and $-3 \mathrm{KBis}$ wells. Note that fracture porosity and permeability values (Zielin-1, depth 3236.50-3237.50 m; Zielin-2, depth $3267.55 \mathrm{~m}$ )

pyrolytically released compounds from heating the sample up to $650{ }^{\circ} \mathrm{C}$ accounted for peak $S_{2}$ (hydrocarbons formed during thermal decomposition of the sample organic matter, were excluded. All depth values refer to measured depths. A1-Werra Anhydrite (Lower Anhydrite + Upper Anhydrite), Ca2 Main Dolomite, $A 2$ basal anhydrite; $M$ mudstone, $W$ wackestone; $P$ packstone; $B$ boundstone; $R+F$ rudstone + floatstone

OM), for which the $T_{\max }$ parameter represents temperature at the maximum rate of hydrocarbon release from the cracking of kerogen during pyrolysis. The released organic origin 
carbon dioxides during this process from the beginning of measurements $\left(300{ }^{\circ} \mathrm{C}\right)$ up to the temperature where a minimum concentration is observed (between 450 and $600{ }^{\circ} \mathrm{C}$ ) was recorded as peak $S_{3}$. The content of residual carbon in the sample recorded as peak $S_{4}$ was achieved by further oxidizing a residual sample in an oven heated to $850{ }^{\circ} \mathrm{C}$ in an oxygen atmosphere and measuring the released carbon dioxide by a TCD detector. Further details of the Rock-Eval equipment, procedures and applications are available in Espitalié et al. (1977), Peters (1986), Peters and Cassa (1994), Lafargue et al. (1998), Behar et al. (2001), and Fowler et al. (2005).

\section{Solvent extraction of rocks and oils}

Nine rock samples selected for biomarker analyses (Table 3) were powdered to grain size $<0.2 \mathrm{~mm}$ (approximately $100 \mathrm{~g}$ ) and further exhaustively Soxhlet extracted using a chloroform-methanol mixture $(93: 7 \mathrm{v} / \mathrm{v})$. The extracts were concentrated by partial solvent evaporation. To prevent loss of extracted low volatile components, the solvent was evaporated on a rotary evaporator at room temperature to a volume of approximately $2 \mathrm{~cm}^{3}$. Macromolecular particulates were removed from the concentrates by filtration on a short $3 \mathrm{~cm}$ chromatographic column (silica gel $60 \mathrm{H}$ ) and the extracted organic matter (EOM) was washed out with the excess of dichloromethane. The obtained solutions of EOM free of particulates were concentrated again prior to further analyses of their molecular composition.

\section{Gas chromatography-mass spectrometry}

Gas chromatography-mass spectrometry (GC-MS) analyses were performed on total (not separated into fractions) crude oils from the Zielin-2 and -3 KBis wells and on oils from five nearest wells surrounding Zielin isolated carbonate platform as well as nine core extracts. The GC separations were achieved with an HP 5890 Series II gas chromatograph equipped with a HP-5 fused silica capillary column (length $30 \mathrm{~m}, 0.25 \mathrm{~mm}$ i.d. and $0.25 \mu \mathrm{m}$ active phase film thickness $-95 \%$ dimethylsiloxane $+95 \%$ diphenylpolysiloxane), interfaced to an HP 5970 MS detector (ionization energy of $70 \mathrm{eV}$, source temperature of $230{ }^{\circ} \mathrm{C}$, TIC mode with 1-s sweeping frequency). GC oven temperature was increased from $35{ }^{\circ} \mathrm{C}$ at $3{ }^{\circ} \mathrm{C} / \mathrm{min}$ to $300{ }^{\circ} \mathrm{C}$ with a hold time at final temperature for $20 \mathrm{~min}$. Saturated hydrocarbon biomarker parameters and aromatic hydrocarbon ratios were calculated from integrated peak areas on the respective ion fragmentograms. Identification of compounds was achieved by the interpretation of relevant mass spectra, literature data, and NIST 02 mass spectral library.

\section{Reflected light microscopy}

Four samples (Table 1) were microscopically studied in reflected $(\lambda=546 \mathrm{~nm})$ monochromatic green light and fluorescent light (UV) to identify macerals from the liptinite group and bituminous impregnations, following procedures described by Taylor et al. (1998). Analyses were carried out on a polarizing Axio Imager Zeiss microscope equipped with a reflectivity photometer PMT 200 to measure OM reflectance. The measurements were performed on grains $>5 \mu \mathrm{m}$ in diameter of polished core sections containing vitrinite macerals or vitrinite-like material in immersion oil $\left(n_{\mathrm{D}}=1.515\right)$ at $20-25^{\circ} \mathrm{C}$ using optic glass of known reflectance $(0.595,0.907$, and $1.722 \%)$ as standards. Quantitative analysis was done by the planimetry method at the micrometer screw gauge resolution of $0.2 \mathrm{~mm}$. Mean random light reflectance of these components shows a direct relationship with thermal maturity of OM in sediments. The nomenclature and classification adopted by the

Table 1 Mean random reflectance of solid bitumen $\left(\mathrm{BR}_{\mathrm{r}}\right)$, range and standard deviation and calculated mean random vitrinite reflectance (VRr) for selected samples from Main Dolomite carbonate rocks of Zielin-1, -2, and -3Kbis wells

\begin{tabular}{llllllll}
\hline Well & Depth $(\mathrm{m})$ & $\mathrm{BR}_{\mathrm{r}}($ range $)(\%)$ & Counts & $\mathrm{OM}\left(\mathrm{SB}, \mathrm{V}^{\mathrm{a}}\right)(\%)$ & $\begin{array}{c}\text { Standard } \\
\text { deviation }\end{array}$ & $\begin{array}{c}\mathrm{VRr}^{\mathrm{b}}(\mathrm{range})(\%) \\
\begin{array}{c}T_{\text {peak }} \text { burial } \\
\text { temperature } \\
\left({ }^{\mathrm{c}} \mathrm{C}\right)\end{array}\end{array}$ \\
\hline Zielin-1 & 3227.5 & $1.30(1.2-1.4)$ & 8 & Trace & 0.10 & $1.47(1.38-1.57)$ & 167 \\
Zielin-2 & 3265.0 & $1.45(1.4-1.5)$ & 10 & Trace & 0.11 & $1.61(1.57-1.66)$ & 174 \\
Zielin-3KBis & 3230.5 & $1.48(1.1-1.65)$ & 89 & 0.3 & 0.091 & $1.64(1.28-1.80)$ & 175 \\
Zielin-3KBis & 3230.8 & $1.45(1.1-1.7)$ & 47 & 0.1 & 0.097 & $1.61(1.28-1.85)$ & 174 \\
\hline
\end{tabular}

$O M$ organic matter

$S B$ solid bitumens

${ }^{\mathrm{a}} V$ vitrinite like maceral

${ }^{\mathrm{b}} \mathrm{VR}_{\mathrm{r}}$ (in \%) calculated from a formula according to Schoenherr et al. (2007): $\mathrm{VR}_{\mathrm{r}}=\left(\mathrm{BR}_{\mathrm{r}}+0.2443\right) / 1.0495$

${ }^{\mathrm{c}}$ Maximum burial temperature $\left(T_{\text {peak }}\right.$ in $\left.{ }^{\circ} \mathrm{C}\right)$ calculated from mean random vitrinite reflectance values, $\left(\mathrm{VR}_{\mathrm{r}}\right.$ in $\left.\%\right)$, following equation evaluated experimentally by Barker and Pawlewicz (1994): $T_{\text {peak }}=\left(\operatorname{lnVR}_{\mathrm{r}}+1.68\right) / 0.0124$ 
International Committee for Petrology of Coal (ICCP) was used to describe the organic components. For extracts in which there was no vitrinite, the calculated reflectance of vitrinite was based on the mean random reflectivity value of the solid bitumen (BRr) according to the formula developed by Schoenherr et al. (2007):

$\left.\mathrm{VR}_{\mathrm{r}}=\left(\mathrm{BR}_{\mathrm{r}}+0.2443\right) / 1.0495\right)$.

Peak paleotemperature was calculated from vitrinite reflectance using the equation evaluated experimentally by Barker and Pawlewicz (1994):

$T_{\text {peak }}=\left(\operatorname{lnVR}_{\mathrm{r}}+1.68\right) / 0.0124$.

\section{Sedimentology and microfacies of $\mathrm{Ca} 2$ carbonate rocks}

The $\mathrm{A} 1$ anhydrite is overlain by $\mathrm{Ca} 2$ limestone (only in Zielin-3KBis well) and dolomite. These reach their maximum thickness in the western part of the platform (nearly $26 \mathrm{~m}$ in the Zielin-1 well), whereas in the eastern part in the Zielin-3 well their thickness is only $1.3 \mathrm{~m}$ (Fig. 3).

In the Zielin-1 well (Fig. 4a-i), the A1 evaporites are overlain by dolomitized intraclastic rudstone and floatstone (1.20 m thick) of the Ca2 (Fig. 4a). Intraclasts $(<3 \mathrm{~cm}$ long at core scale) are composed of grainstone and packstone. The horizon is overlain by intraclastic-bioclastic packstone ( $3.8 \mathrm{~m}$ thick) covered by boundstone ( $0.2 \mathrm{~m}$ thick) composed of fragments of planar stromatolite followed by a bed of massive anhydrite (3.4 m thick) with dolomitic laminae (Fig. 4b) and laminated mudstone. The latter has a fractured contact with the anhydrite bed, characteristic of desiccation cracks. Fractures are filled with anhydrite. These are followed by an 11.8-m-thick section of intraclastic and bioclastic packstone (Figs. 4c, 5a), intraclastic rudstone/floatstone with biolaminae (1 $\mathrm{m}$ thick) and peloidal wackestone (stabilized by microbial laminae) with a 3-m-thick bed of intraclastic rudstone terminated by biogenic boundstone (microbial bindstone, biolaminite). The concentration of bioclasts is locally so high that they form a coquina. Characteristic features are a cavernous structure and mouldic porosity (Fig. 4d). The breccias and conglomerates are composed of fragments of peloidal, peloidal-bioclastic wackestone, and boundstone (Fig. 4e). The Ca2 interval terminates with a 2-m-thick bed of bioclastic packstone stabilized by microbially derived components and biogenic boundstone (stromatolites, Fig. 4f) $0.3 \mathrm{~m}$ thick, the latter underlying the A2 anhydrite (boundary indicated by an arrow in Fig. $4 \mathrm{~g}$ ). In the Zielin-2 and -3 wells, $\mathrm{Ca} 2$ carbonate rocks are relatively thin ( $3.2 \mathrm{~m}$ and $1.3 \mathrm{~m}$, respectively) and consist of different lithofacies than in the Zielin-1 well. In the Zielin-2 well
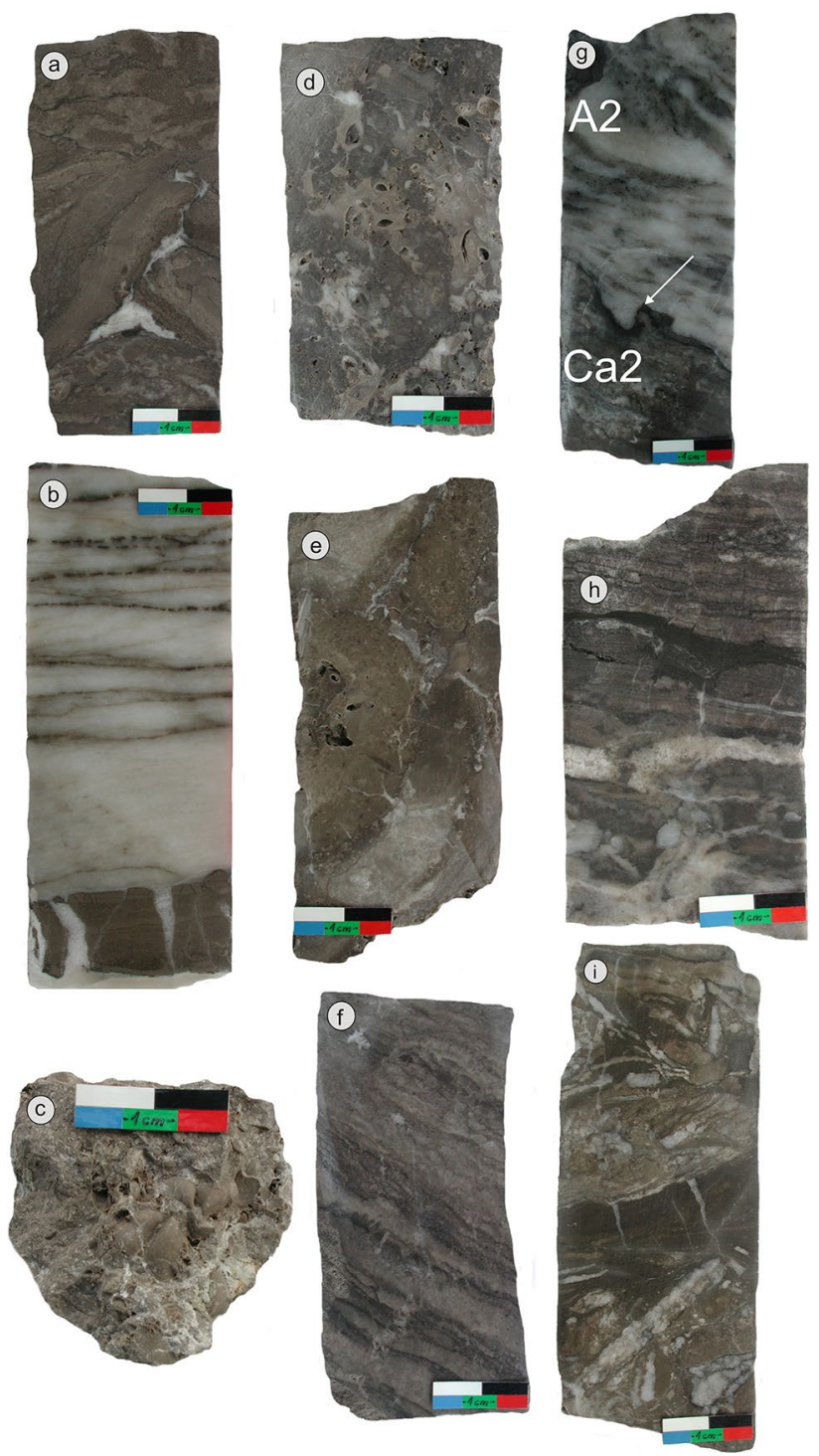

Fig. 4 Lithofacies of Main Dolomite (Ca2) carbonates in the Zielin wells. a Intraclastic rudstone and floatstone, depth $3248.3 \mathrm{~m}$-Zielin-1 well. b Anhydrite bed with dolomitic laminae possibly represents sediments deposited in a small isolated platform depression (restricted lagoon); obvious erosional contact with cracks and fissures, depth $3244.3 \mathrm{~m}$-Zielin-1 well. c Coquina dolomite, depth $3227.1 \mathrm{~m}$-Zielin-1 well. d Coquina dolomite with cavernous structure and mouldic porosity, depth $3224.4 \mathrm{~m}$-Zielin-1 well. e Breccia composed of fragments of peloidal, peloidal-bioclastic wackestone and fragments of boundstone, depth $3224.6 \mathrm{~m}$-Zielin-1 well. f Stromatolitic boundstone, depth $3222.8 \mathrm{~m}$-Zielin-1 well. g Erosional contact of stromatolitic boundstone $(\mathrm{Ca} 2)$ and massive anhydrite with pseudomorphs after selenite gypsum crystals (A2) depth 3223.7Zielin-1 well. h Intraclastic dolograinstone and dolopackstone with anhydrite veins, depth $3264.8 \mathrm{~m}$-Zielin-2 well. i Intraclastic packstones and biogenic boundstone (microbial bindstone) with broken laminae, desiccation cracks, and anhydrite nodules originated in the sabkha environment, depth 3232.5 m-Zielin-3 well

they are dominated by intraclastic dolomitized packstone with bioclasts (Figs. 4h, 5b), overlain by biogenic boundstone (microbial bindstone) whereas in Zielin-3 well they 

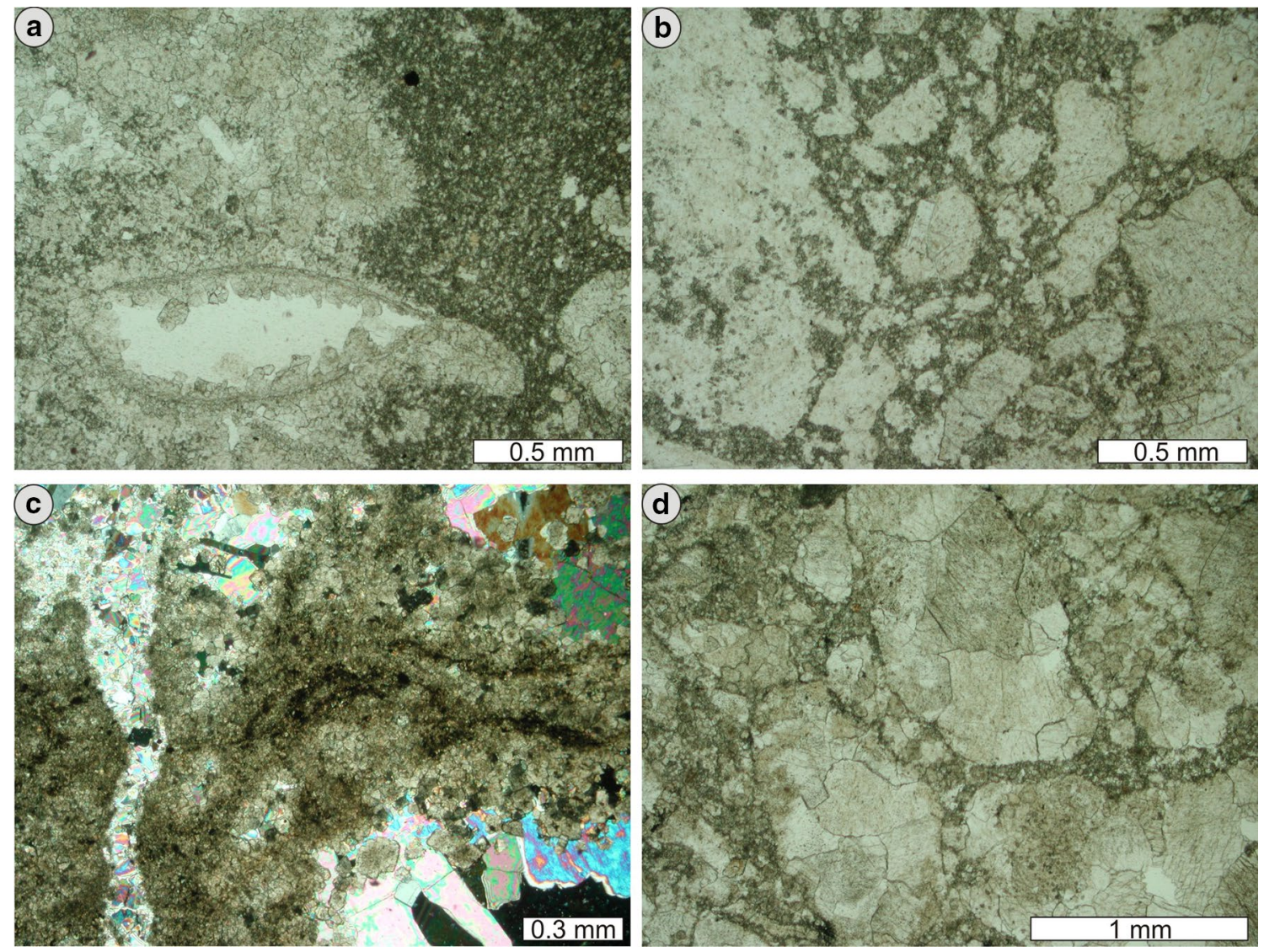

Fig. 5 Photomicrographs of $\mathrm{Ca} 2$ carbonate rocks: a Dolomitized intraclastic and bioclastic packstone. Dolomitic micrite (dark) contacts with sparry dolomite intraclasts (bright): a fragment of a bivalve shell with mouldic porosity-plane light, depth $3237.2 \mathrm{~m}$, Zielin-1 well; b dolomitized intraclastic packstone-plane light, depth

are represented by intraclastic packstone and microbial bindstone in which occur broken laminae, desiccation cracks, and anhydrite nodules (Figs. 4i, 5c).

The Zielin-3 KB is well is a deviated well drilled from Zielin-3 (like Zielin-3K, see Fig. 1) with a total thickness of $23.8 \mathrm{~m}$ for $\mathrm{Ca} 2$. The available core shows that the upper part of the section is represented by dolomitic clast-supported breccias, which pass into mud-supported towards the middle of the section. Clasts are elongate and sharp-edged up to $2 \mathrm{~cm}$ long, although some are rounded (mud clasts $<5 \mathrm{~mm}$ in length), composed of mudstone, stromatolite (planar and columnar), and thrombolite (clotted). Common dissolution vugs and small caverns are filled with anhydrite cement. Overall, the lithology has a characteristic rudstone texture. Mud-supported breccias pass into light-grey lime mudstone towards the base. Lime mudstone (dedolomites?) with sporadic wavy lamination is interbedded with clast-supported breccias formed of elongate clasts of mudstone $(<1.5 \mathrm{~cm}$ in length), microbial fragments and coarse-grained material characteristic of a rudstone texture (Fig. 5d), which completes the section.
$3266.0 \mathrm{~m}$, Zielin-2 well; c dolomitized microbial bindstone, dark micritized biolaminae cut by an anhydrite vein-polarized light, depth $3233.0 \mathrm{~m}$, Zielin-3 well; d clast-supported breccia, lime rudstone-depth $3245.0 \mathrm{~m}$, Zielin-3KBis well

The Ca2 carbonate rocks are overlain by A2 light blue anhydrite, which is partly laminated with pseudomorphs after selenite gypsum crystals. Anhydrite reaches a maximum thickness of $207 \mathrm{~m}$ in the eastern part of the Zielin isolated carbonate platform (Zielin-2 well), thickening from $87.5 \mathrm{~m}$ in the west, to form an anhydrite swell.

The contact between the $\mathrm{Ca} 2$ and $\mathrm{A} 2$ anhydrite is irregular and distorted indicating an erosional surface, likely resulting from subaerial exposure and termination of carbonate sedimentation (Fig. 4g; Peryt 1986; Slowakiewicz and Mikolajewski 2009). The entire $\mathrm{Ca} 2$ interval shows rapid environmental changes related to the end of carbonate deposition in the PZ2 cycle. Intraclasts may have been derived from the upper part of the platform, which suggests that the Zielin-1 well was drilled close to the platform slope. Similarly, the Zielin-3Kbis well was drilled through $\mathrm{Ca} 2$ slope lithofacies, mostly represented by rudstone. An anhydrite bed with dolomitic laminae in the Zielin-1 well possibly represents deposition in a restricted hypersaline lagoon. Dolomitic laminae may have a microbial origin whereas dolomitic clasts were derived from platform erosion. Laminated 
dolomudstone has laminae derived from the growth of anhydrite cement filling voids and small fissures. Massive anhydrite with pseudomorphs after selenite gypsum crystals suggests precipitation in a subaqueous environment generally characterized by a high salinity (Peryt 1994).

The overall sedimentary and microfacies pattern of the Zielin isolated carbonate platform reflects its shallow-water origin and the regressive character of the $\mathrm{Ca} 2$ sea, typical of isolated and off-platform highs described from adjacent areas or other parts of the Ca2 sea (Strohmenger et al. 1993; Peryt and Dyjaczyński 1991; Kosakowski and Krajewski 2015).

\section{Reservoir properties}

Petrographic studies show that the best reservoir properties occur in bioclastic packstone, which has a well-developed mouldic porosity, and in intraclast packstone/grainstone (Figs. 3 and 6). In general, porosity in Zielin wells varies between 0.1 and $20 \%$ (Fig. 3). The pore system is mainly intergranular and was enhanced during early burial dissolution through dolomitization. Subsequently, porosity was reduced because of late anhydrite cementation of $\mathrm{Ca} 2$ strata, which led to occlusion of the pore network. Finally, porosity was enhanced by fractures, stylolites and microstylolites during late-burial diagenesis (notably dedolomitization). Permeability values range from 0.001 to $6600 \mathrm{mD}$ (Fig. 3), with the latter values commonly related to fractures (Fig. 5b). As presented in Fig. 3 the best petrophysical properties are within an 11-m-thick intraclastic and bioclastic dolopackstone and peloidal dolowackestone of the Zielin-1 well and in some portions of intraclastic dolopackstone of the Zielin-2 well. Thus, the highest porosity and permeability values are associated with fractures, which are a very common feature in $\mathrm{Ca} 2$ carbonate rocks in general (Reijers 2012).

\section{D seismic interpretation of the Zielin isolated carbonate platform area}

On time slices of the PZ2 cycle base in the Zielin area, there is a well-imaged system of radial faults in a circular or elliptical central region (Figs. 7, 8a). Reservoirs associated with salt diapirs are known to be segmented by similar radial or concentric faults (Rank-Friend and Elders 2004; Stewart 2006). The concentric fault configuration is probably due to vertical movements in the central area of the volcanic cone. Radial dislocations are observed as faults rooted in the $\mathrm{A} 1$ anhydrite, cutting the $\mathrm{Ca} 2$ carbonate rocks and $\mathrm{A} 2$ anhydrite.

During Late Rotliegend time, the Zielin paleovolcano was eroded but it may subsequently have been uplifted during post-orogenic vertical movements of the Variscan basement, which continued until the early Zechstein. This uplift influenced the thickness of the Main Dolomite carbonates on the Zielin paleohigh.
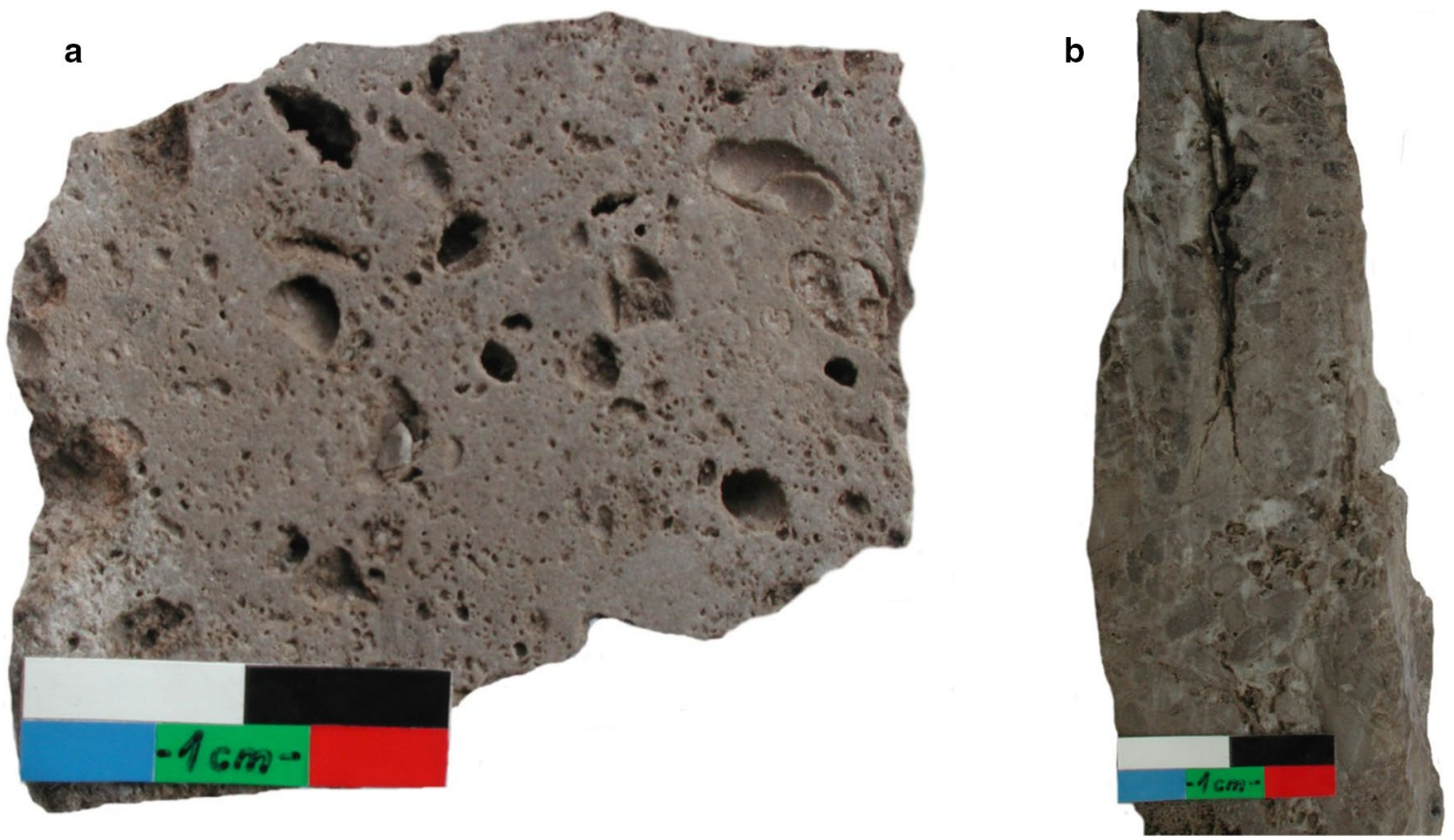

Fig. 6 Main Dolomite reservoir porosity in Zielin wells: a mouldic porosity in Main Dolomite bioclastic packstone, Zielin-1 well, depth $3225.7 \mathrm{~m}$; b fracture (in the upper part of the core) in Main Dolomite bioclastic packstone, Zielin-3KBis well, depth $3227.7 \mathrm{~m}$ 

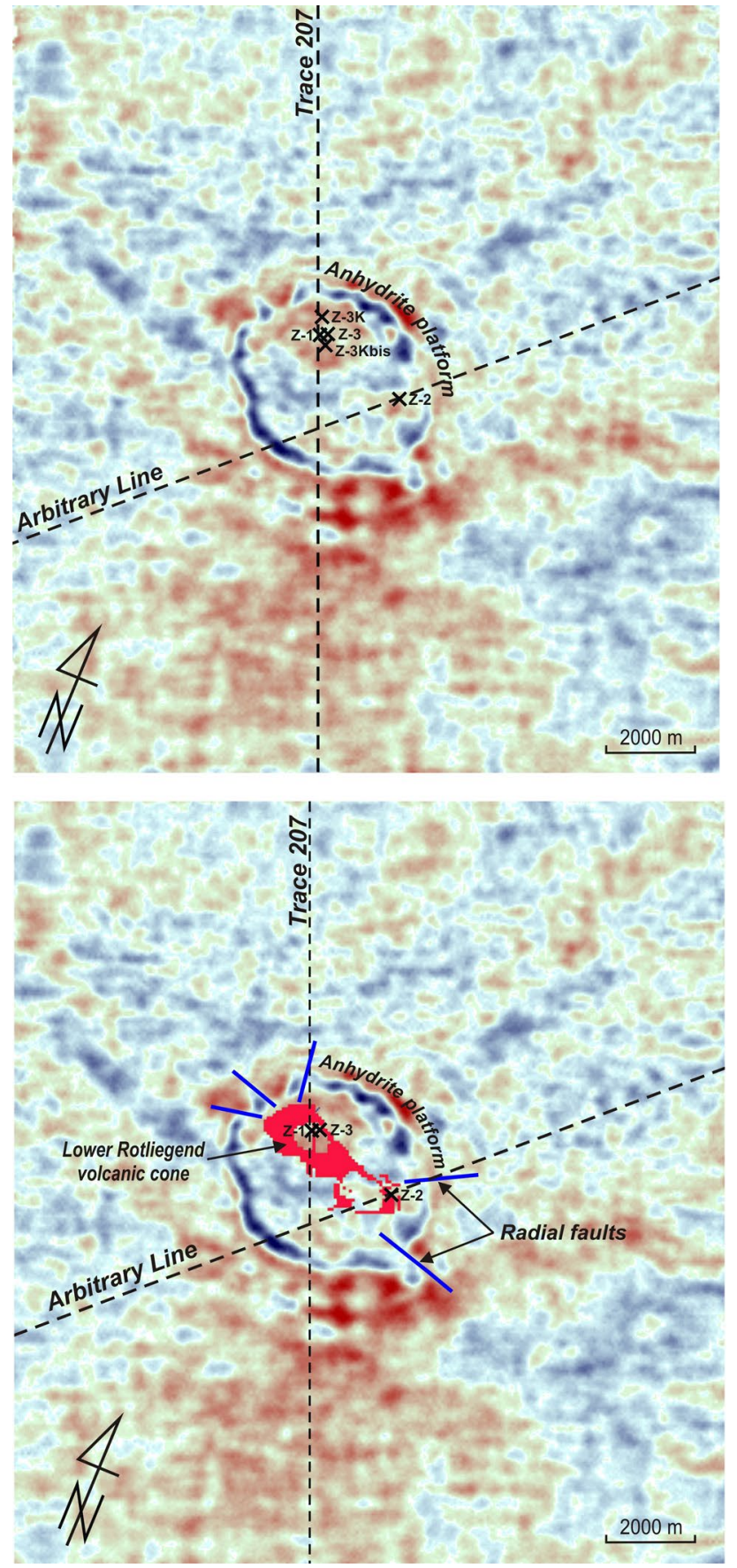

Fig. 7 Horizontal seismic line $1976 \mathrm{~ms}$ (time slice) across the Zielin structure (3D seismic survey, Geofizyka Toruń 1997). Note probable radial faults in the Lower Rotliegend volcanic cone overlain by Zechstein anhydrite platform (A1 anhydrite) deposits

The thickness of $\mathrm{Ca} 2$ carbonate rocks at Zielin could not be accurately interpreted from $3 \mathrm{D}$ seismic data. Where $\mathrm{Ca} 2$ strata are more than $20 \mathrm{~m}$ thick and porosities are $>0-15 \%$, below the Z2 positive seismic reflector [top Basal Anhydrite (A2)/bottom Older Halite (Na2)], a negative reflector is present near the top of the Main Dolomite $(\mathrm{Ca} 2 \mathrm{str}=$ bottom
Ca2). This commonly occurs around the nearby BMB field in Ca2 strata (Kwolek and Mikolajewski 2010). The presence of this reflector helps to map the extent of the $\mathrm{Ca} 2$ reservoir. With the Zielin isolated carbonate platform, both the porosity (mean 5-6\%) and the thickness $(4.5-25 \mathrm{~m})$ of the $\mathrm{Ca} 2$ carbonate rocks are too small for the interval to be detected on seismic images. At the toe-of-slope/lower slope and slope of the platform where the A2 anhydrite is only 5-10 m thick, the Z2 seismic reflector approximates to the top of the $\mathrm{Ca} 2$ interval (Fig. 8). However, on the isolated high top, where the A2 anhydrite is $207 \mathrm{~m}$ thick, the Ca2 and $\mathrm{A} 2$ sections are "split" and hence the $\mathrm{Z} 2$ reflector does not represent the top-Ca2.

The extent of Ca2 strata is also difficult to determine due to the scale of the sub-Zechstein volcanic rocks. This is because the volcanic cone is small: around $2 \mathrm{~km}$ across in a NW-SE direction and $1 \mathrm{~km}$ across NE-SW. A very steep slope of the cone's surface up to $80-90^{\circ}$ makes seismic imaging difficult.

Seismic interpretation and identification of isolated platforms and buildups have recently been discussed by Burgess et al. (2013), who, based on 234 seismic images, presented identification criteria to distinguish isolated carbonate buildups from non-isolated ones. Groetsch and Mercandier (1999) and Posamentier et al. (2010) described Neogene examples of isolated carbonate buildups imaged on 2D and 3D seismic data. However, Zielin-like carbonate platforms, which developed on a sulphate platform, and where deposition was controlled by an eroded shield volcano were not discussed. Some similarities to the development of the Zielin isolated carbonate platform can be found in isolated carbonate platforms formed on volcanic cones offshore Myanmar and in the Maldives (Belopolsky and Droxler 2003; Paumard et al. 2017), yet these grew directly on topographic highs of the faulted volcanic basement, without any sulphate platforms, and they form a chain of carbonate atolls.

\section{Organic matter petrography and vitrinite reflectance}

The samples analyzed are very poor in OM content, from trace amounts (samples from the Zielin-1 well, depth $3227.5 \mathrm{~m}$ and the Zielin-2 well, depth $3265.0 \mathrm{~m}$ ) to 0.1 and $0.3 \%$ of the planimetry surface in samples from the Zielin-3KBis well, depth 3230.8 and $3230.5 \mathrm{~m}$, respectively (Table 1). The organic material consists mostly of solid bitumen (SB) and single fragments of vitrinite-like (collinite) material $\left(\mathrm{V}^{*}\right)$. Solid bitumen occurs as thin veins and tiny grains and is abundant in clayey intercalations within dolomites (Fig. 9a). It commonly occurs in dolomites as material occluding pore entries and fissures. Under UV light rare bituminous impregnations are observed (Fig. 9b). Measured 

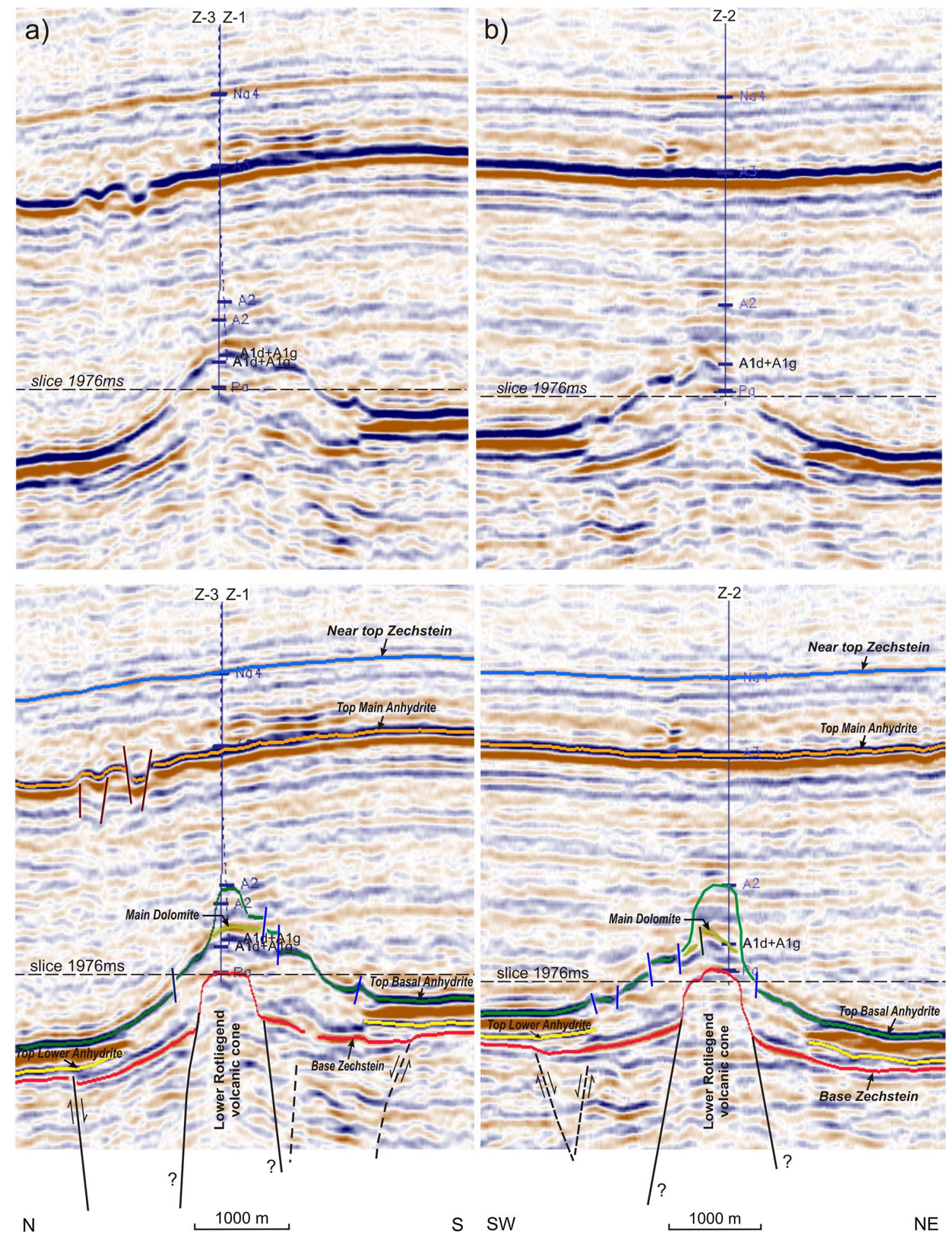

Fig. 8 Seismic cross sections through the Zielin structure. a Northsouth seismic section across the Zielin structure-time slice $1976 \mathrm{~ms}$ is shown in Fig. 7b. b SW-NE section across the Zielin structure.

solid bitumen reflectances $\left(\mathrm{BR}_{\mathrm{r}}\right)$ are from 1.1 to $1.7 \%$ with mean random values in the range of 1.3-1.48\% (Table 1). The mean random reflectances on the vitrinite scale $\left(\mathrm{VR}_{\mathrm{r}}\right)$

Symbols Z-1, Z2, Z-3 refer to Zielin-1, -2, and -3 wells. For explanation, see 3D seismic survey, Geofizyka Toruń, 1997-Fig. 7. A1d, A1 g-Lower Anhydrite and Upper Anhydrite, respectively

calculated for the studied samples from the $\mathrm{BR}_{\mathrm{r}}$ according to Schoenherr et al. (2007) have values within the range of $1.47-1.64 \%$ (Table 1). In addition, assessed burial peak 

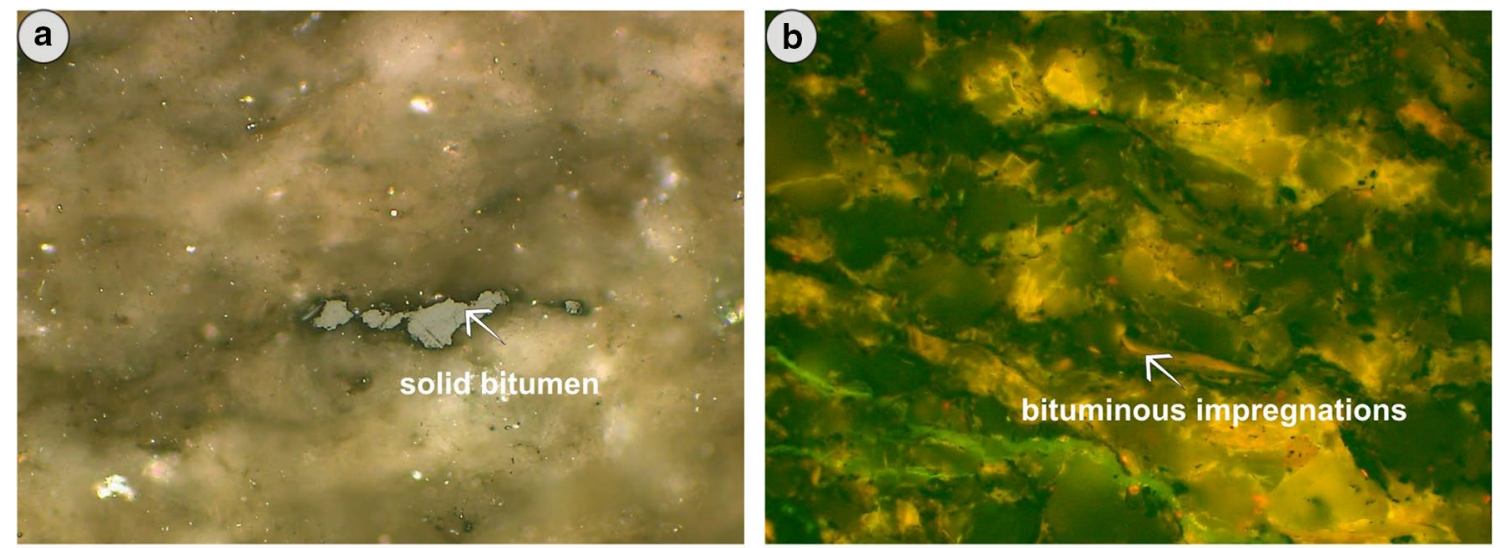

$\underline{40 \mu m}$

Fig. 9 Photomicrographs of solid bitumen from Zechstein Main Dolomite carbonate rock. a Solid bitumen in peloidal-bioclastic packstone, white light; $\mathrm{VR}_{\mathrm{r}} 1.61 \%$; depth $3265.0 \mathrm{~m}$, Zielin-2 well. b Bitu-

paleotemperatures from $\mathrm{VR}_{\mathrm{r}}$ using the equation of Barker and Pawlewicz (1994) are in the range of $167-175^{\circ} \mathrm{C}$. Thus, maturity based on SB or on the dominant macerals within SB indicates the zone of 'gas window'.

\section{Geochemical evaluation}

\section{Rock-Eval pyrolysis}

Rock-Eval pyrolysis was performed on twenty-seven carbonate samples. For most samples, it was found that the TOC content is at the level of analytical error, i.e., $<0.1 \%$, and only four samples were in the range of $0.1-0.3 \mathrm{wt} \%$ (Table 2). The HI for the latter is low in the range from 42 to $105 \mathrm{mg} \mathrm{HC} / \mathrm{g}$ TOC. Data on the $S_{3}$ parameter are not included in Table 2 because their values are very low (average $0.2 \mathrm{mg} \mathrm{CO}_{2} / \mathrm{g}$ rock). In view of the possible thermal decomposition of carbonaceous rocks, interpretation of $S_{3}$ and hence the OI values are unreliable. Based on TOC, $S_{1}$ and $S_{2}$ values it would appear most likely that the hydrocarbons have migrated into the carbonate matrix of the Zielin isolated carbonate platform. Only accessory low kerogen content is present at some levels. The value of the thermal maturity parameter $T_{\max }$ for carbonate rock from Zielin$3 \mathrm{KBis}$, depth $3244.1 \mathrm{~m}$ is $463{ }^{\circ} \mathrm{C}$. This value is consistent with related data obtained by Kotarba et al. (2000) from wells Zielin-1 and Zielin-3KBis, Kotarba and Wagner (2007) and Kosakowski and Krajewski (2014, 2015) for $\mathrm{Ca} 2$ carbonate rocks in the eastern and southern part of the Gorzów Block and the northern part of the Wielkopolska Platform (Fig. 1). The carbonate-containing accessory kerogen has production indices (PI) ranging from 0.34 to 0.82 , which is consistent with the high maturity indicated by $T_{\max }$. minous impregnations in rudstone/floatstone, UV light; $\mathrm{VR}_{\mathrm{r}} 1.64 \%$, depth $3230.5 \mathrm{~m}$, Zielin-3KBis well

These data are in accordance with the high mean random $\mathrm{VR}_{\mathrm{r}}$ values (range, 1.47-1.64\%, see Table 1).

\section{Molecular composition of hydrocarbons and dibenzothiophenes}

Hydrocarbons from analyzed carbonate rocks and oils from the Zielin isolated carbonate platform are dominated by compounds containing the aliphatic chain. Chromatographic profiles of $n$-alkanes and isoprenoids in the crude oils from the Zielin-2, and -3KBis wells and independently in the extracted bitumen (EOM) from the $\mathrm{Ca} 2$ cores of the Zielin-1, -2, and -3KBis wells show similarity in their molecular composition. Representative mass chromatograms of $n$-alkanes and isoprenoids in oil (upper trace) and in EOM from the core at a depth of $3245.6 \mathrm{~m}$ (lower trace) from the Zielin-3KBis well are shown in Fig. 10. The oil is characterized by an $n$-alkane profile showing a steady decrease in homolog abundance with increasing chain length (illustrated in Fig. 10 profile for $n-\mathrm{C}_{9+}$ ) and no carbon number predominance. In the case of the EOM, except for a steady decrease in abundance within the lower molecular $n$-alkanes up to $n-\mathrm{C}_{15}$, these additionally display a characteristic Gaussian homological distribution within the range $n-\mathrm{C}_{16}-n-\mathrm{C}_{37}$ with a maximum abundance for the $n-\mathrm{C}_{22}$ homologue, typical of marine-derived OM. For samples from the Zielin isolated carbonate platform, the diagram developed by Shanmugam (1985) of the $\mathrm{Pr} / n-\mathrm{C}_{17}$ versus $\mathrm{Ph} / n-\mathrm{C}_{18}$ ratios (data given in Table 3 ) is illustrated in Fig. 11. The abundance of pristane and phytane relative to adjacent $n$-alkanes results in average $\mathrm{Pr} / n-\mathrm{C}_{17}$ and $\mathrm{Ph} / n-\mathrm{C}_{18}$ values of 0.50 and 0.75 , respectively. A very close location of the points on the diagram indicates the similarity of the OM source, depositional environment and maturity. It is designated for kerogen type II deposited 
Table 2 Rock-Eval data of organic matter in the Main Dolomite carbonate samples from Zielin-1, Zielin-2, and Zielin-3KBis wells

\begin{tabular}{|c|c|c|c|c|c|c|c|}
\hline Well & Depth (m) & TOC (wt $\%)$ & $T_{\max }\left({ }^{\circ} \mathrm{C}\right)$ & $\begin{array}{l}S_{1}(\mathrm{mg} \\
\mathrm{HC} / \mathrm{g} \text { rock })\end{array}$ & $\begin{array}{l}\mathrm{S}_{2}(\mathrm{mg} \\
\mathrm{HC} / \mathrm{g} \text { rock })\end{array}$ & PI & $\begin{array}{l}\mathrm{HI}(\mathrm{mg} \\
\mathrm{HC} / \mathrm{g} \\
\mathrm{TOC})\end{array}$ \\
\hline Zielin-1 & 3224.3 & 0.01 & Ur & 0.12 & 0.00 & - & - \\
\hline Zielin-1 & 3225.3 & 0.01 & Ur & 0.06 & 0.00 & - & - \\
\hline Zielin-1 & 3227.5 & 0.17 & Ur & 0.11 & 0.17 & 0.39 & 100 \\
\hline Zielin-1 & 3227.8 & 0.01 & Ur & 0.06 & 0.00 & - & - \\
\hline Zielin-1 & 3231.6 & 0.01 & Ur & 0.13 & 0.00 & - & - \\
\hline Zielin-1 & 3234.5 & 0.01 & Ur & 0.08 & 0.00 & - & - \\
\hline Zielin-1 & 3236.6 & 0.05 & Ur & 0.31 & 0.01 & - & - \\
\hline Zielin-1 & 3237.4 & 0.02 & Ur & 0.26 & 0.00 & - & - \\
\hline Zielin-1 & 3239.0 & 0.03 & Ur & 0.35 & 0.00 & - & - \\
\hline Zielin-1 & 3245.9 & 0.00 & Ur & 0.13 & 0.00 & - & - \\
\hline Zielin-1 & 3247.2 & 0.00 & Ur & 0.05 & 0.00 & - & - \\
\hline Zielin-1 & 3247.8 & 0.01 & Ur & 0.15 & 0.08 & - & - \\
\hline Zielin-2 & 3263.8 & 0,01 & Ur & 0.10 & 0.00 & - & - \\
\hline Zielin-2 & 3264.0 & 0.12 & Ur & 0.02 & 0.05 & 0.34 & 42 \\
\hline Zielin-2 & 3264.4 & 0.01 & Ur & 0.05 & 0.00 & - & - \\
\hline Zielin-2 & 3265.2 & 0.00 & $\mathrm{Ur}$ & 0.03 & 0.00 & - & - \\
\hline Zielin-2 & 3265.5 & 0.02 & Ur & 0.19 & 0.03 & - & - \\
\hline Zielin-2 & 3265.6 & 0.00 & Ur & 0.08 & 0.00 & - & - \\
\hline Zielin-2 & 3266,2 & 0.05 & Ur & 0.20 & 0.02 & - & - \\
\hline Zielin-2 & 3266,6 & 0.06 & Ur & 0.37 & 0.00 & - & - \\
\hline Zielin-2 & 3267.2 & 0.04 & Ur & 0.27 & 0.00 & - & - \\
\hline Zielin-3KBis & 3227.1 & 0.02 & Ur & 0.21 & 0.02 & - & - \\
\hline Zielin-3KBis & 3229.5 & 0.05 & Ur & 0.59 & 0.10 & - & - \\
\hline Zielin-3KBis & 3230.5 & 0.29 & Ur & 0.10 & 0.21 & 0.33 & 72 \\
\hline Zielin-3KBis & 3241.2 & 0.08 & Ur & 0.48 & 0.01 & - & - \\
\hline Zielin-3KBis & 3244.1 & 0.19 & 463 & 0.92 & 0.20 & 0.82 & 105 \\
\hline Zielin-3KBis & 3245.6 & 0.02 & $\mathrm{Ur}$ & 0.27 & 0.04 & - & - \\
\hline
\end{tabular}

TOC total organic carbon, $T_{\max }$ the maximum rate of hydrocarbons released during pyrolysis $S_{2}$ peak, $S_{1}$ free hydrocarbons, $S_{2}$ residual hydrocarbon generating potential, $P I$ production index, $S_{1} /\left(S_{1}+S_{2}\right), H I$ hydrogen index, $N d$ not determined, $U r$ unreadable value under anoxic water column conditions as is rationalized by lower unity $\mathrm{Pr} / \mathrm{Ph}$ values (Table 3). A higher $\mathrm{Pr} / \mathrm{Ph}$ values for oils (average 0.85) compared to EOM's (average 0.70) is the result of the oils' higher maturity. It is illustrated in an enlarged part of the diagram (Fig. 11) showing the slightly higher maturity of oils (filled, shaded points) as compared to extracted bitumen (empty points). A high degree of genetic similarity between the EOM and oils analyzed from the Zielin isolated carbonate platform, both vertical and regional, indicates their common source.

Classic biomarkers were observed only in the carbonate rock sample from the Zielin-3KBis well, depth $3229.5 \mathrm{~m}$, where steranes (Fig. 12) and hopanes (Fig. 13) were found. This rock sample is characterized by a very low $S_{2}(0.1 \mathrm{mg}$ $\mathrm{HC} / \mathrm{g}$ rock), which identifies it as the very poor source rock. Concentrations of the above biomarkers in $\mathrm{Ca} 2$ samples from the Zielin-1, -2 and -3KBis wells are characterized by lower $S_{2}$ values, which approach the limit of detection, whereas in oils the steranes and hopanes are absent.

Steranes in the Zielin-3KBis core sample are composed of $\mathrm{C}_{29}$ and $\mathrm{C}_{27}$ regular and rearranged structures dominating the homological distribution (Fig. 12). The pronounced concentration of diasteranes $(13 \alpha 17 \beta$ and $13 \beta 17 \alpha$, R and $\mathrm{S}$ structures) as compared to regular steranes ( $\alpha \alpha \alpha$ and $\alpha \beta \beta$, $\mathrm{R}$ and $\mathrm{S}$ structures) indicates mineral matrix heterogeneity with the presence of clay constituents in the carbonate matrix (intraclasts). The $\mathrm{C}_{29}$ regular sterane stereoisomerization and $S /(S+R)$ and $\alpha \beta \beta /(\alpha \alpha \alpha+\alpha \beta \beta)$ ratios are at equilibrium values of 0.54 and 0.62 , respectively, and are consistent with the offset hydrocarbon generation zone (Peters et al. 2005).

Terpanes in Zielin-3KBis core sample at a depth of $3229.5 \mathrm{~m}$ are represented by relatively low amounts of tricyclic terpanes $(23 \mathrm{Tr}-26 \mathrm{Tr})$, traces of tetracyclic terpanes (not marked) and dominance of regular hopanes 


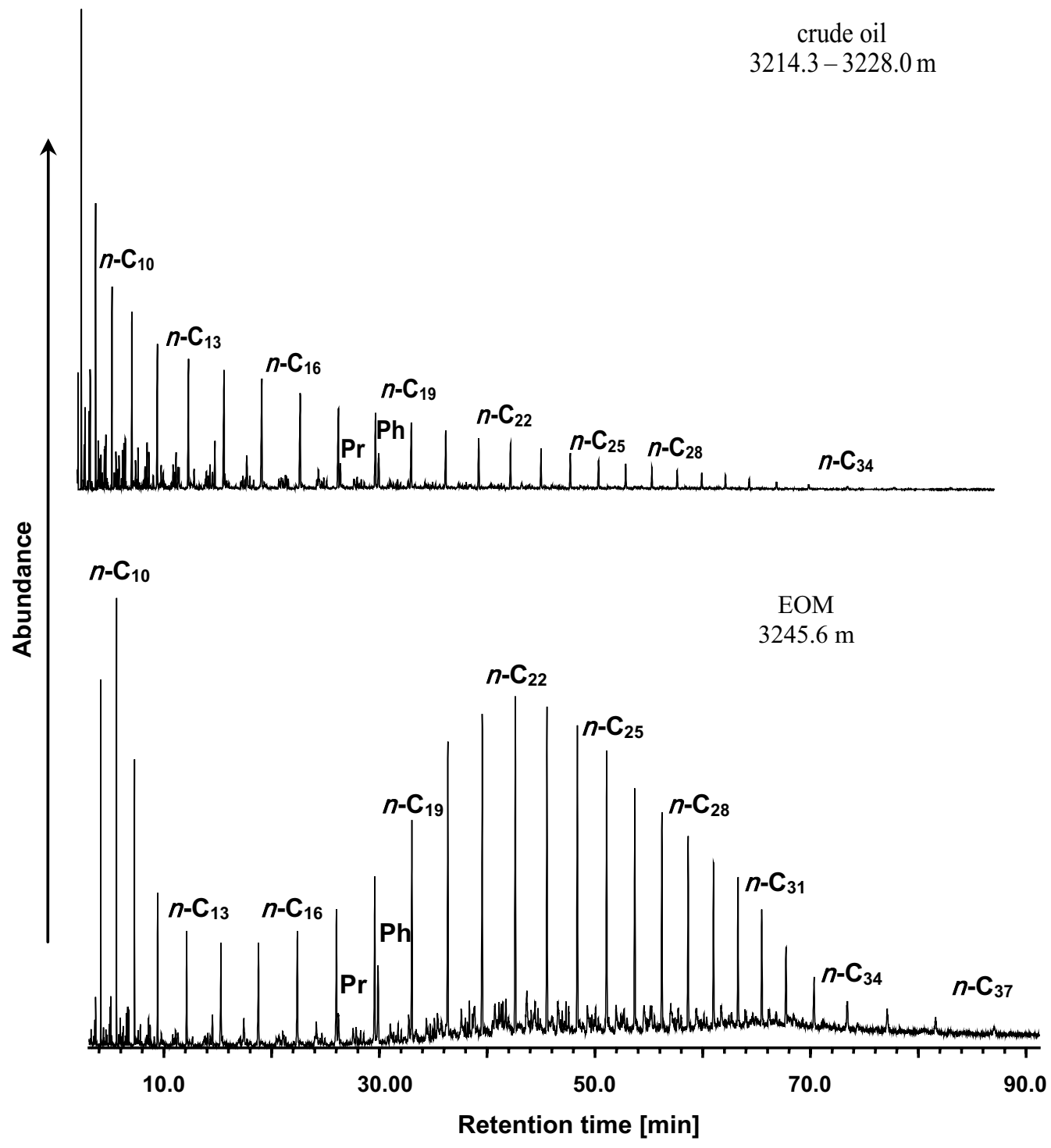

Fig. 10 Homologous distribution of $n$-alkanes and acyclic isoprenoids in crude oil (upper mass chromatogram) and extractable organic matter (EOM) from $\mathrm{Ca} 2$ core (depth $3245.6 \mathrm{~m}$ ) of the Zielin-3KBis well

(Fig. 13), where the $\mathrm{C}_{30} \alpha \beta$ hopane is the most prominent. The pentacyclic triterpanes are characterized by Ts/Tm ratio (Ts-18 $\alpha(\mathrm{H}) 22,29,30$-trisnorneohopane, $\mathrm{Tm}-17 \alpha(\mathrm{H}) 22,29,30$-trisnorhopane) close to unity, a smooth decrease of $\mathrm{C}_{31}-\mathrm{C}_{35}$ extended hopane abundance with increasing homologue carbon number and their stereochemical equilibration as well as a rather low abundance of gammacerane $(\mathrm{G})$. This suggests the presence of suboxic conditions during OM deposition in a moderately saline water column, with a maturity that reached the stage of the oil window. As discussed by Moldowan et al. (1991), the terpane signature with reference to the noted high content of diasteranes in sterane composition (Fig. 12), as well as the observed slightly marked unresolved complex mixture in the aliphatic compounds of one particular sample (not shown), are a reflection of the clay-minerals present at this depth $(3229.5 \mathrm{~m})$, where partial microbial reworking of the deposited algal OM took place. This is probably the result of episodic suboxic conditions in the shallow-water column (Słowakiewicz et al. 2015, 2016) around the Zielin-3Kbis well area.

The cross-plot developed by Hughes et al. (1995) for a wide maturity range of hydrocarbons, expressed as the dependence of dibenzothiophene/phenanthrene ratio (DBT/P) vs. $\mathrm{Pr} / \mathrm{Ph}$ ratio, is useful in determining the depositional environment of a source rock and the lithology in which it was generated. However, the dibenzothiophene compounds are not inherited from biomass components, 
Table 3 Geochemical molecular indices of oils and extractable organic matter in the Main Dolomite carbonate samples from the Zielin-1, Zielin-2, and Zielin-3KBis wells as well as oils from the nearest wells surrounding Zielin isolated carbonate platform

\begin{tabular}{|c|c|c|c|c|c|c|c|c|c|c|c|c|}
\hline Well name & Depth (m) & $N-\mathrm{C}_{10} / \mathrm{N}$ & $\mathrm{Pr} / \mathrm{Ph}$ & $\operatorname{Pr} / n-\mathrm{C}_{17}$ & $\mathrm{Ph} / n-\mathrm{C}_{18}$ & 2-MN/1-MN & $\begin{array}{l}\mathrm{C}_{21} / \mathrm{C}_{20} \\
n \text {-AlkBe }\end{array}$ & MPI-1 & $\mathrm{VR}_{\mathrm{c}}(\%)$ & $\mathrm{DBT} / \mathrm{P}$ & MDR & $\begin{array}{l}\mathrm{VR}_{\mathrm{m}} \\
{[\%]}\end{array}$ \\
\hline \multicolumn{13}{|c|}{ Extracted organic matter from carbonate rocks of Zielin isolated carbonate platform } \\
\hline Zielin-1 & 3236.6 & - & 0.32 & 0.63 & 0.96 & - & - & - & - & - & 2.51 & 0.69 \\
\hline Zielin-1 & 3247.8 & 0.89 & 0.45 & 0.39 & 0.69 & 1.62 & 1.82 & 0.63 & 0.78 & 0.85 & 3.09 & 0.74 \\
\hline Zielin-2 & 3264.0 & - & 0.37 & 0.48 & 0.67 & - & - & - & - & - & 2.04 & 0.67 \\
\hline Zielin-2 & 3265.5 & 1.42 & 0.52 & 0.42 & 0.71 & 1.21 & 1.63 & 0.69 & 0.82 & 0.57 & 3.15 & 0.74 \\
\hline Zielin-2 & 3266.2 & - & 0.30 & 0.59 & 0.76 & - & - & - & - & - & - & \\
\hline Zielin-3KBis & 3229.5 & 1.50 & 0.43 & 0.60 & 0.79 & 1.31 & 1.06 & 0.76 & 0.85 & 0.63 & 2.57 & 0,70 \\
\hline Zielin-3KBis & 3241.2 & - & 0.30 & 0.52 & 0.82 & - & - & - & - & - & - & - \\
\hline Zielin-3KBis & 3244.1 & - & 0.32 & 0.48 & 0.71 & - & - & - & - & - & 2.49 & 0.69 \\
\hline Zielin-3KBis & 3245.6 & 1.62 & 0.50 & 0.53 & 0.84 & 1.18 & 1.30 & 0.63 & 0.78 & 0.52 & 1.90 & 0.65 \\
\hline \multicolumn{13}{|c|}{ Crude oils from the Zielin isolated carbonate platform and from the nearest surrounding wells of the Gorzów platform } \\
\hline Różańsko-4 & $3188.5-3201.5$ & 4.61 & 0.95 & 0.28 & 0.38 & 2.56 & 0.99 & 1.64 & 1.38 & 33.3 & 3.64 & 0.78 \\
\hline Zielin-2 & $3264.0-3269.0$ & 14.72 & 0.89 & 0.49 & 0.66 & 1.60 & 0.97 & 0.90 & 0.90 & 1.36 & 2.80 & 0.71 \\
\hline Zielin-3KBis & $3214.3-3228.0$ & 11.00 & 0.83 & 0.50 & 0.69 & 1.47 & 1.16 & 0.82 & 0.82 & 1.91 & 2.91 & 0.72 \\
\hline Namyślin-1 & $3140.0-3143.0$ & 19.43 & 0.77 & 0.47 & 0.69 & 1.15 & 1.10 & 0.74 & 0.84 & 2.41 & 3.53 & 0.77 \\
\hline Barnówko-3 & $3051.5-3106.5$ & 10.17 & 0.68 & 0.63 & 1.16 & 1.28 & 1.96 & 1.29 & 1.17 & 1.56 & 3.89 & 0.79 \\
\hline Mostno-2 & $3032.5-3066.0$ & 11.53 & 0.73 & 0.53 & 0.94 & 1.60 & 1.49 & 1.31 & 1.19 & 1.12 & 4.01 & 0.80 \\
\hline Cychry-2 & $3299.0-3016.5$ & 20.83 & 0.80 & 0.55 & 0.98 & 1.14 & 1.72 & 0.55 & 0.73 & 2.25 & 5.62 & 0.92 \\
\hline
\end{tabular}

$n-\mathrm{C}_{10} / \mathrm{N}$-decane/naphthalene ratio, $P r / P h$ pristane/phytane ratio, $\mathrm{Pr} / n-\mathrm{C}_{17}$ ratio; $\mathrm{Ph} / n-\mathrm{C}_{18}$ ratio, 2-MN/1-MN 2-methylnaphthalene/1-methylnaphthalene ratio, $C_{21} / C_{20} n$-AlkB $\mathrm{C}_{21} / \mathrm{C}_{20} n$-alkylbenzenes ratio, $M P I$ methylpehnanthrene index, $D B T / P$ dibenzothiophene/phenanthrene ratio, $M D R$ dibenzothiophene index

$\mathrm{VRc}=0.40+0.60 \times \mathrm{MPI}-1$ and $\mathrm{VR}_{\mathrm{m}}=0.073 \times \mathrm{MDR}+0.51$ - equivalents of vitrinite reflectance assessed from MPI- 1 and MDR, respectively (Radke 1988)

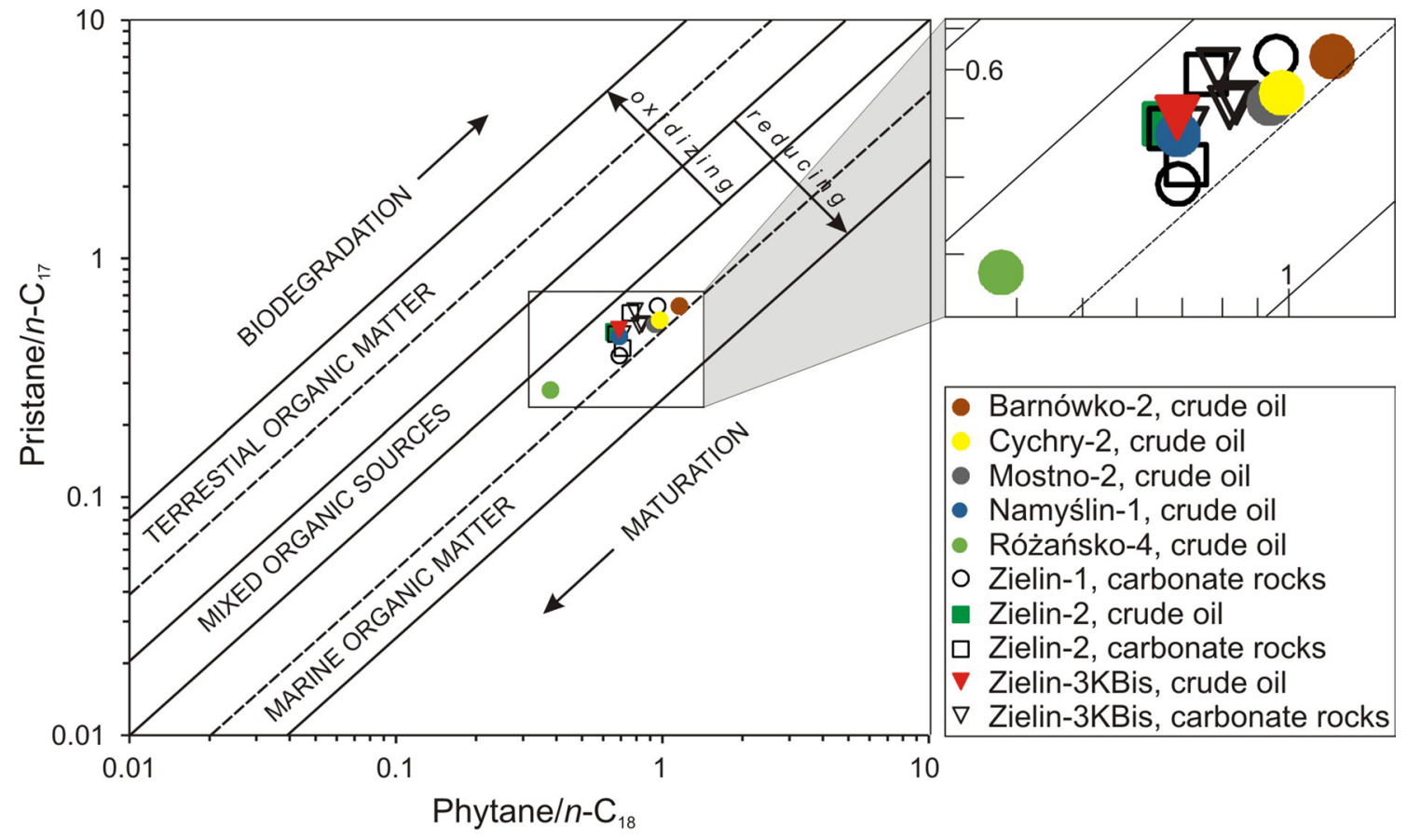

Fig. 11 Genetic characteristics of oils and extractable organic matter from carbonate rocks of Zielin isolated carbonate platform wells with an applied correlation of pristane $/ n-\mathrm{C}_{17}$ and phytane $/ n-\mathrm{C}_{18}$ ratios (Shanmugam 1985) 


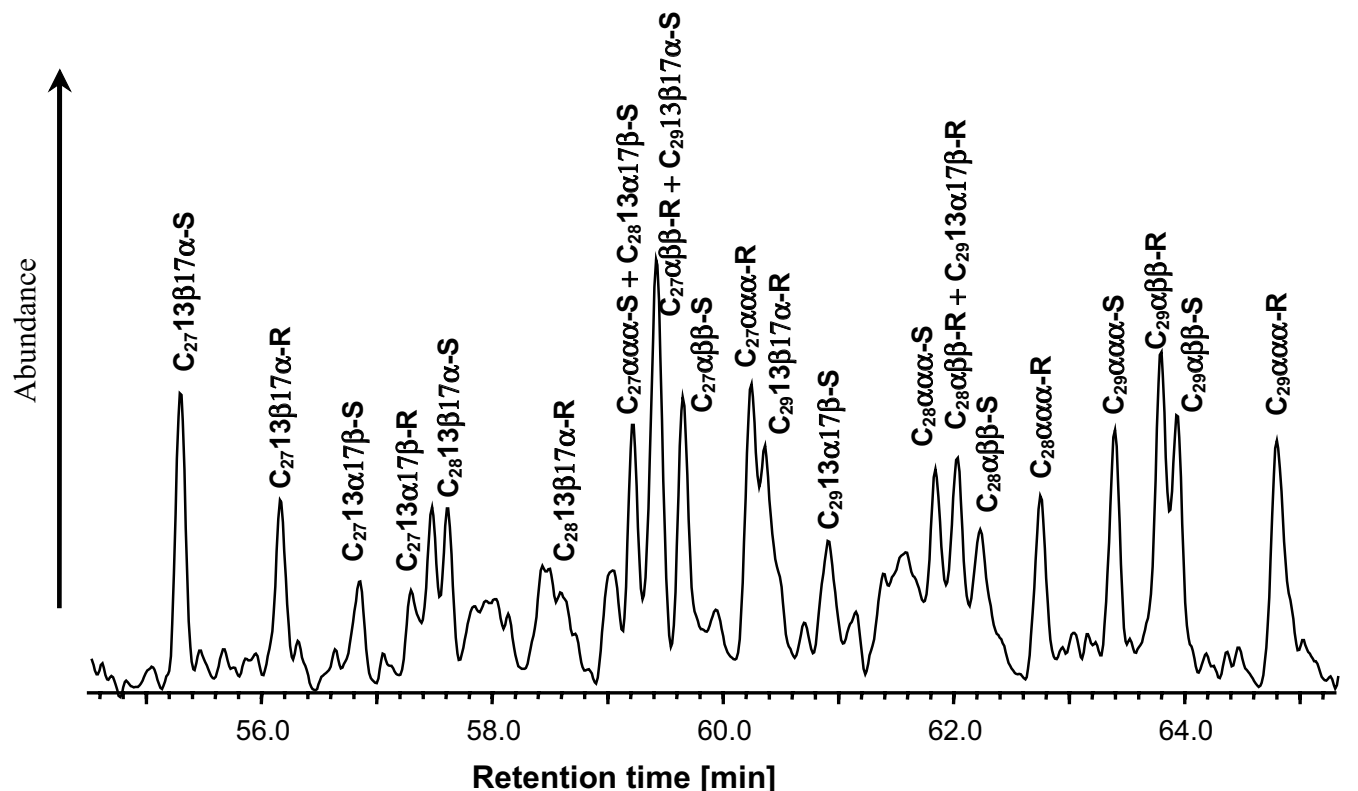

Fig. 12 Molecular composition of steranes in extracted organic matter from Ca2 core at a depth of $3229.5 \mathrm{~m}$ in the Zielin-3KBis well

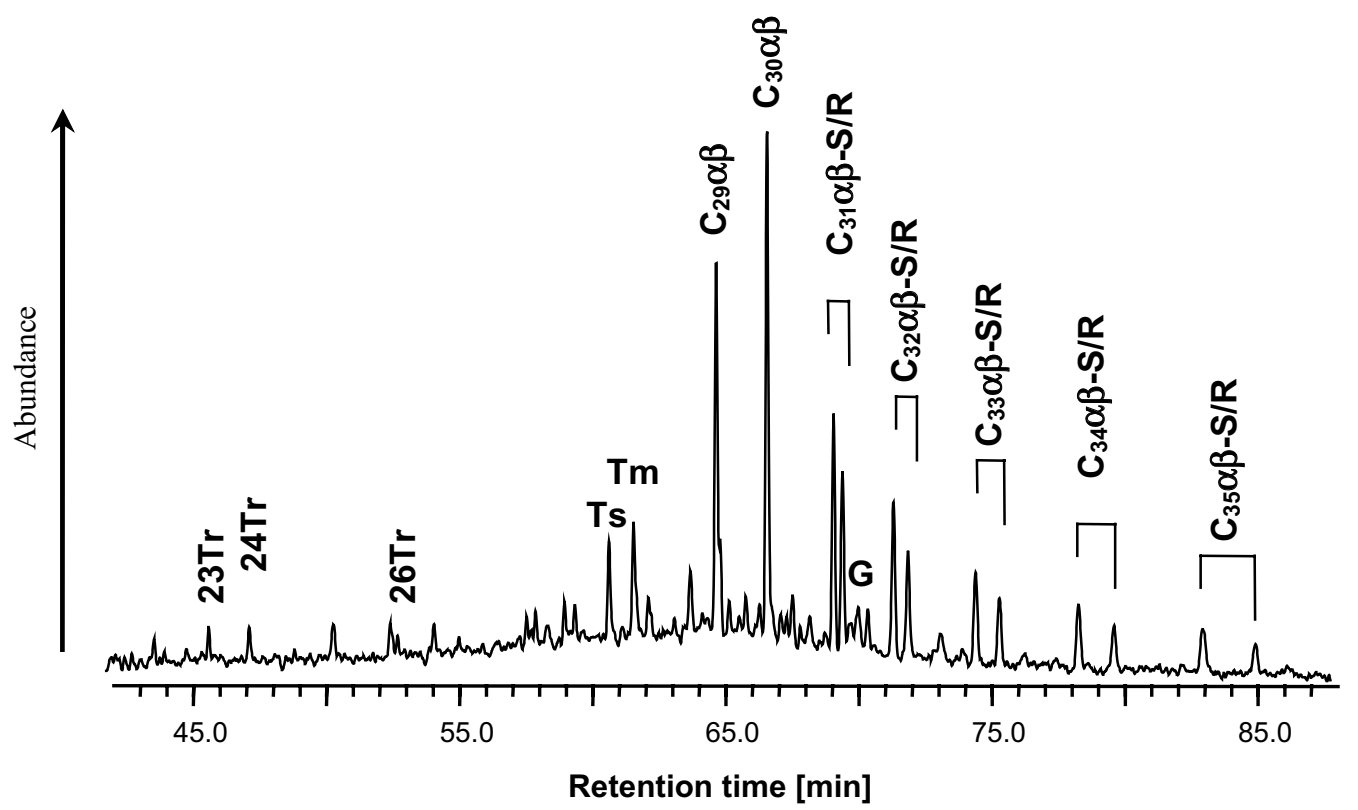

Fig. 13 Molecular composition of tri- (Tr) and pentacyclic triterpanes in extracted organic matter from $\mathrm{Ca} 2$ core at a depth of $3229.5 \mathrm{~m}$ of the Zielin-3KBis well. $23 \operatorname{Tr} \mathrm{C} 23$ tricyclic terpane, $24 \mathrm{Tr}$ C24 tricyclic terpane, 26Tr C26 tricyclic terpane, Ts $18 \alpha(\mathrm{H}), 21 \beta(\mathrm{H})$ 22,29,30-trisnorhopane, Tm $17 \alpha(\mathrm{H}), 21 \beta(\mathrm{H})-22,29,30$-trisnorhopane, $C_{27}-17 \beta \quad 17 \beta(\mathrm{H})-22,29,30$-trisnorhopane, $\quad C_{29} \alpha \beta \quad 17 \alpha(\mathrm{H}), 21 \beta(\mathrm{H})-$

but they are the geochemical products controlled by the availability of the reduced sulphur-hydrogen sulphide for incorporation into deposited OM. In oil and gas deposits, hydrogen sulphide is formed mainly by sulphate reduction via a thermochemical reaction with hydrocarbon norhopane, $C_{30} \alpha \beta 17 \alpha(\mathrm{H}), 21 \beta(\mathrm{H})$-hopane, $C_{31} \alpha \beta$-S/R 17 $\alpha(\mathrm{H}), 21 \beta(\mathrm{H})$ homohopane (22S/22R), $C_{32} \alpha \beta-S / R 17 \alpha(\mathrm{H}), 21 \beta(\mathrm{H})$-bishomohopane (22S/22R), $C_{33} \alpha \beta-S / R \quad 17 \alpha(\mathrm{H}), 21 \beta(\mathrm{H})$-trishomohopane (22S/22R), $C_{34} \alpha \beta-S / R 17 \alpha(\mathrm{H}), 21 \beta(\mathrm{H})$-tetrakishomohopane (22S/22R), $C_{35} \alpha \beta-S / R$ $17 \alpha(\mathrm{H}), 21 \beta(\mathrm{H})$-pentakishomohopane (22S/22R)

compounds, thus its concentration is dependent on rock lithology (presence of anhydrite) and depth (Marriott et al. 2016). The data of the DBT/P vs. $\mathrm{Pr} / \mathrm{Ph}$ ratio for oils fall into the source rock zone associated with a marine carbonate/ marl lithology, and for the EOM into the zone associated 
with lacustrine sulphate-poor deposits of variable lithology (Table 3, Fig. 14). The slightly higher DBT/P ratios for analyzed oils from the Zielin isolated carbonate platform as compared to extracted bitumen from the rocks of respective wells are resulting from their slightly higher maturity (see also Słowakiewicz et al. 2018 and data calculated from MPI-1 values corresponding to random mean vitrinite reflectance $\mathrm{VR}_{\mathrm{c}}$ given in Table 3) and contacting with reduced sulphur during hydrocarbon migration. The relative concentration of methyldibenzothiophene homologues was found to be sensitive to hydrocarbon maturity. The commonly used dibenzothiophene index (MDR, Radke et al. 1986; Radke 1988), a maturity parameter based on the 4-methyldibenzothiophene/1-methyldibenzothiophene ratio, indicates a maturity corresponding to an advanced stage of the oil window (data on MDR and equivalent random vitrinite reflectance $\mathrm{VR}_{\mathrm{m}}$ values are presented in Table 3).

\section{Oil migration into the Zielin isolated carbonate platform}

The Rock-Eval data of the analyzed $\mathrm{Ca} 2$ cores show that the Zielin isolated carbonate platform contains a very low level or no kerogen. It indicates a migration origin for the hydrocarbons accumulated in the Zielin atoll, possibly from the $\mathrm{Ca} 2$ carbonate basin surrounding the isolated platform. This result has led to a search for the pathway of their inflow to the atoll. For this purpose, we performed organic geochemical analyses of selected $\mathrm{Ca} 2$ core samples from Zielin wells as well as crude oils from the Zielin isolated carbonate platform and from the nearest surrounding wells of the Gorzów platform, i.e., Różańsko-4, Barnówko-3, Mostno-2, Namyślin-1 and Cychry-2 wells (Table 3, location of wells in Fig. 15). As a measure of the crude oil migration direction, the values of $n$-decane/naphthalene $\left(n-\mathrm{C}_{10} / N\right)$ concentration ratio in the respective samples were assumed (Table 3 ). Since straight chained hydrocarbons migrate more easily than aromatic hydrocarbons a pathway of increasing values of the $n-\mathrm{C}_{10} / N$ ratio determines the direction of hydrocarbon migration. These values for the oils from respective wells (data in Table 3) show increasing trend from Różańsko-4 oil (4.6) through Barnówko-3, Mostno-2, Zielin-2 and -3KBis oils (average 11.8) to Cychry-2 and Namyślin-1 oils (average 20.1), indicating the main direction of hydrocarbon migration in the region from $\mathrm{NE}$ to $\mathrm{SW}$, as marked with a red arrow in Fig. 15. Much lower values of the $n-\mathrm{C}_{10} / N$ ratio in

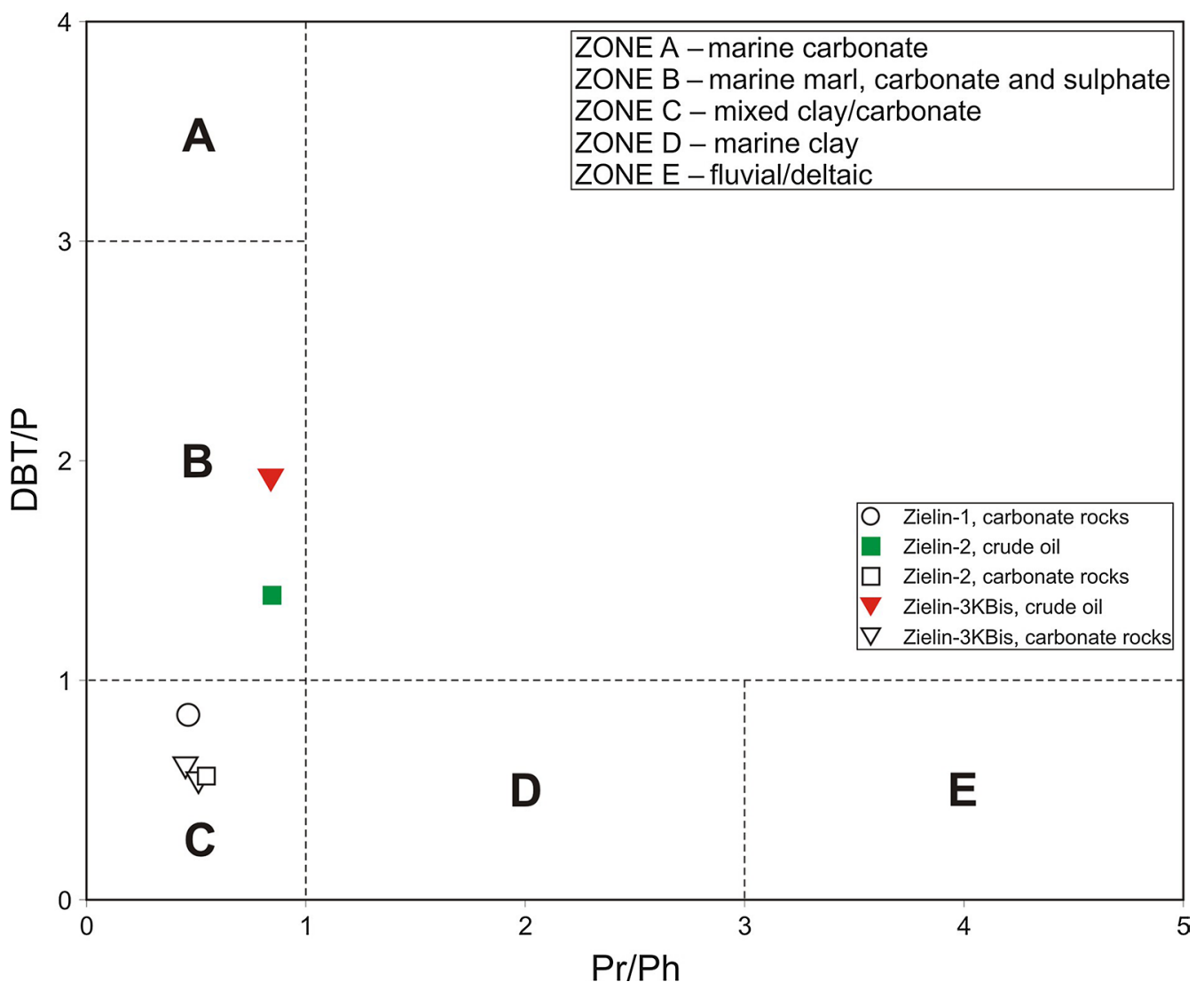

Fig. 14 A cross-plot of the dibenzothiophene/phenanthrene ratio (DBT/P) vs. the pristane/phytane ( $\mathrm{Pr} / \mathrm{Ph})$ ratio indicating depositional environment and lithology (Hughes et al. 1995; fields updated after Słowakiewicz et al. 2018) 


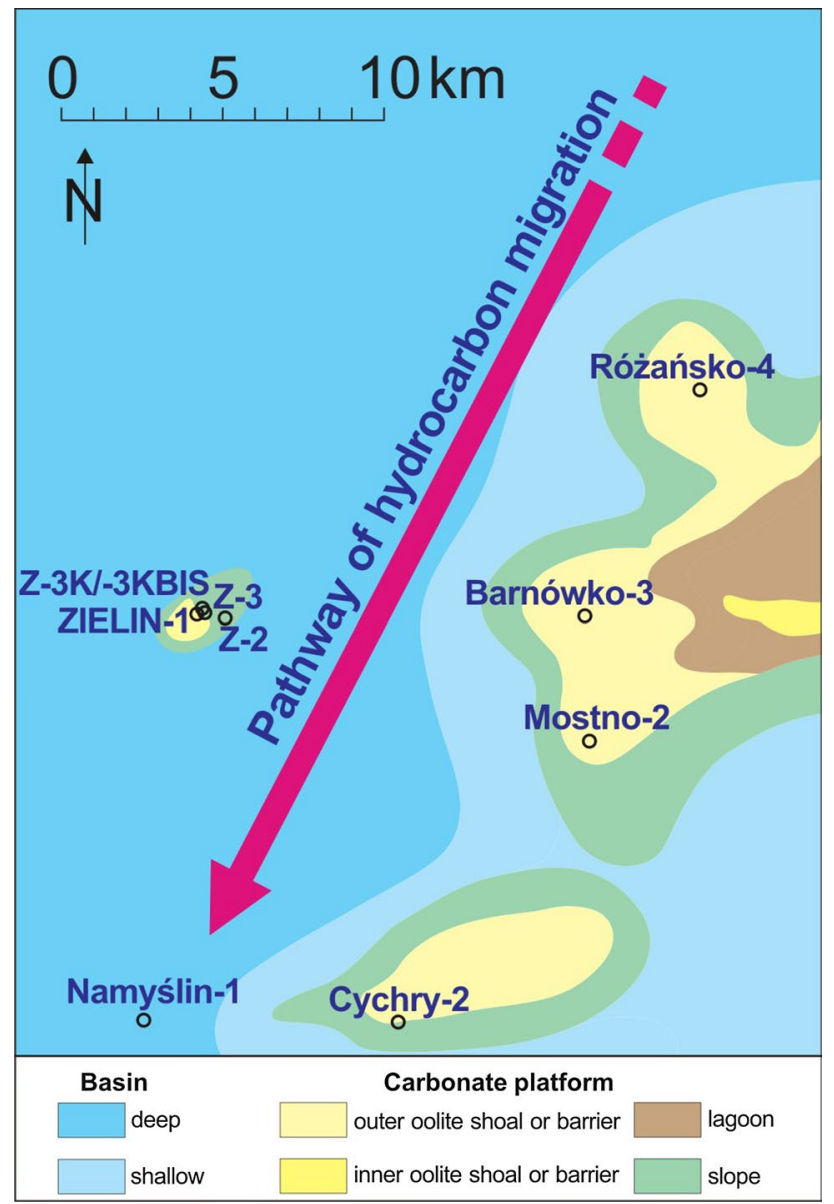

Fig. 15 The main pathway (red arrow) of hydrocarbon migration from the deeper basin towards the BMB and other smaller isolated platforms ( $\mathrm{Ca} 2$ paleoenvironments after Kotarba and Wagner 2007, modified)

the EOM from Zielin Ca2 cores could result from preferential sorption of naphthalene on carbonate grains as compared to $n$-decane and, additionally, partial evaporation of $n$-decane during sample laboratory preparation. Thus these much-distorted data are not relevant to the hydrocarbon migration assessment. The observed decreasing trend of the oil hydrocarbon maturity from respective wells determined by $2-\mathrm{MN} / 1-\mathrm{MN}$ ratio and MPI-1 index (data in Table 3) also roughly follow their migration direction as indicated in Fig. 15. This trend expressed by vitrinite reflectance $\left(\mathrm{VR}_{\mathrm{c}}\right)$ calculated from MPI-1 is within the range from 1.38 to $0.73 \%$. These data show that the maturity of accumulated oils in $\mathrm{Ca} 2$ isolated platforms in the SW of the region correspond to the peak oil window where respective values for oils from the Cychry- 2 and Namyślin- 1 wells are 0.73 and $0.84 \%$, whereas in the NE of the region to the end of the oil window where for oil from Różańsko-4 well it is $1.38 \%$. Within the area of the Barnówko-3, Mostno-2, Zielin-2 and $-3 \mathrm{~KB}$ is wells the hydrocarbons have intermediate maturity; however, oils from the Zielin atoll located in the western part of the region have a lower maturity than those from the Barnówko-3 and Mostno-2 wells located in its eastern part (Fig. 15). It might also suggest that another possible pathway of hydrocarbon migration in the region proceeds in the direction from $\mathrm{E}$ to $\mathrm{W}$. Thus, further research was undertaken to find out which pathway of hydrocarbon migration is likely to be the major one. To solve this, analyzed oil accumulations in different isolated $\mathrm{Ca} 2$ platforms (BMB, Cychry, Zielin, Namyślin) were compared to see if they have a common source. For this purpose, molecular compositions of selected compound classes, i.e., sesquiterpanes, $n$-alkylbenzenes and polyalkylnaphthalenes, were considered. A summary comparative illustration of partial mass chromatograms of the compound classes is illustrated in Fig. 16.

Sesquiterpanes with drimane skeletal units originating from bacteria and algae are ubiquitous components of crude oils (Noble et al. 1987; Volkman 1988). It has been suggested that the proportion of rearranged structures in total drimanes may be related to maturity whereas the ratio of homodrimane to drimane may be related to depositional environment (Weston et al. 1989). Thus, sesquiterpanes have become increasingly used as a highly diagnostic tool for differentiation, correlation and source identification of crude oils. Comparative mass chromatographic illustration of sesquiterpane composition in the analyzed crude oils is shown in Fig. 16 (column A). This illustration clearly differentiates the oils into two distinct groups. The first group (I) represents oils from Różańsko-4, Zielin-2 and -3Kbis and Namyślin-1 wells where in sesquiterpane composition 4,4,8,8,9-diadrimane (structure (3) in Fig. 16, column (A)) far predominates whereas the second group (II) represents oils from Barnówko-3, Mostno-2 and Cychry-2 where in the sesquiterpanes, except high abundance of 4,4,8,8,9-diadrimane also $8 \beta(\mathrm{H})$-drimane and $8 \beta(\mathrm{H})$-homodrimane [structures (5) and (10) in Fig. 16, column (A)] are present in dominant relative concentration. Within the group II oils a gradual decrease of $8 \beta(\mathrm{H})$-drimane and $8 \beta(\mathrm{H})$-homodrimane concentration is observed as compared to the concentration of 4,4,8,8,9-diadrimane on a transect from the Barnówko-3 through Mostno-2 to Cychry-2 wells, parallel to the transect from NE to SW indicated with a red arrow in Fig. 15. The sesquiterpane compositional oils group I and II diversity is most probably a result of a diverse biogenic input to their source of OM.

The above supposition is supported by the $n$-alkylbenzenes composition in the analyzed crude oils. As recognized earlier, this compound class is controlled by source input, depositional environments and maturity (Sinninghe Damsté et al. 1991, 1993; Hartgers et al. 1994; Pedentchouk et al. 2004), where some alkylbenzenes preserve information about their biological precursors (Zhang et al. 2014). The $n$-alkylbenzene profiles shown in Fig. 16 (column B) display 


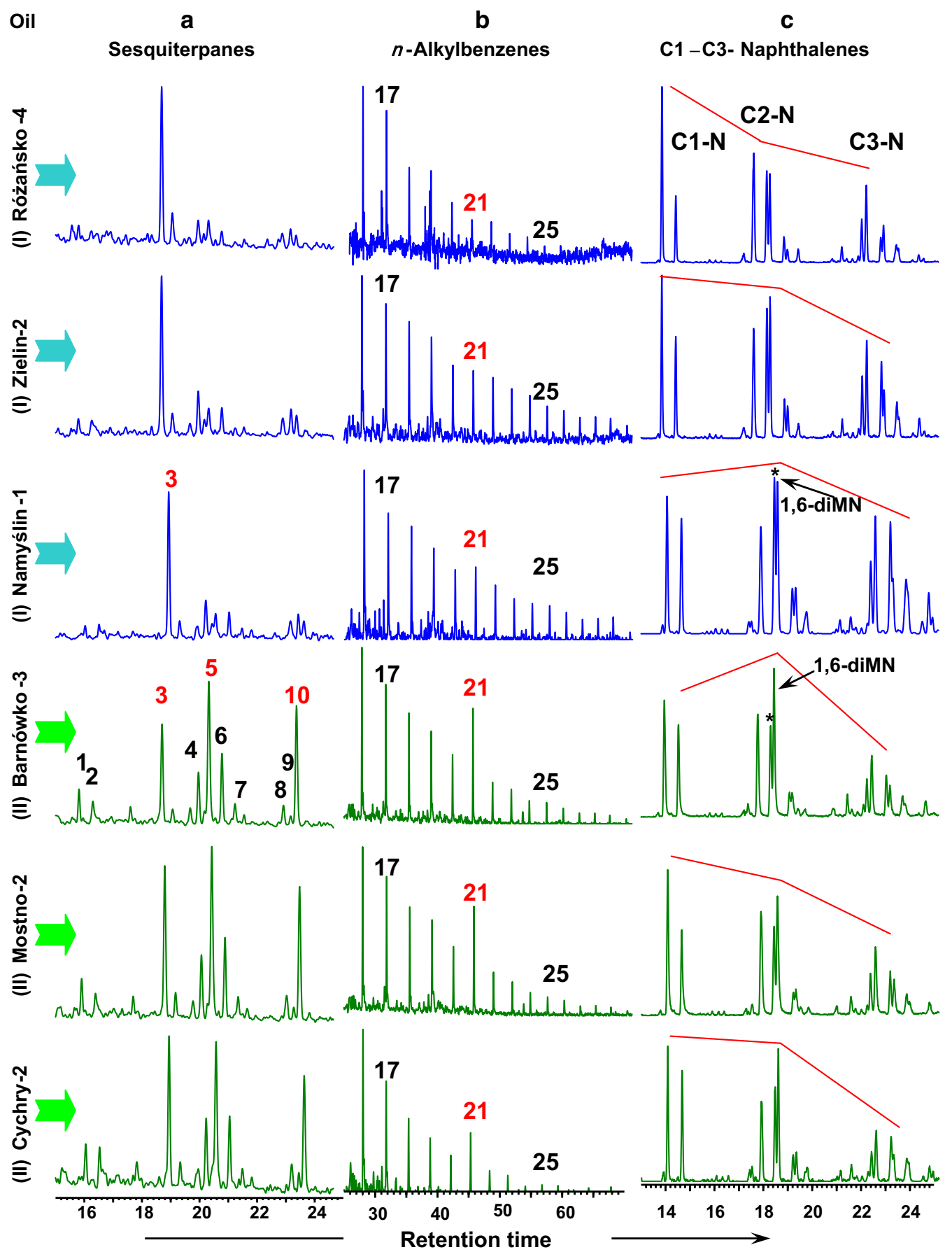

Fig. 16 Mass chromatogram profiles of sesquiterpanes $(\mathrm{m} / \mathrm{z}$ 123), $n$-alkylbenzenes $(\mathrm{m} / \mathrm{z} \quad 92)$ and $\mathrm{C} 1-\mathrm{C} 3$-naphthalenes $(\mathrm{m} / \mathrm{z}$ $142+156+170)$ in the oils analysed. Column (A)-sesquiterpanes(1) and (2) nordrimanes $-\mathrm{C}_{14} \mathrm{H}_{26}$ etramethyldecahydronaphthalenes, (3) 4,4,8,8,9-diadrimane- $-\mathrm{C}_{15} \mathrm{H}_{28}$ pentamethyldecahydronaphthalene, (4) 4,4,8,9,9-diadrimane $-\mathrm{C}_{15} \mathrm{H}_{28}$ pentamethyldecahydronaphthalene, (5) $8 \beta(\mathrm{H})$-drimane $-\mathrm{C}_{15} \mathrm{H}_{28}$, (6) rearranged drimane $-\mathrm{C}_{15} \mathrm{H}_{28}$ penta-

a decreasing trend of the homologue relative abundance with increasing carbon numbers up to $\mathrm{C}_{30}$ homologue. However, in the studied oils assigned to group II (Barnówko-3, methyldecahydronaphthalene, (7), (8), and (9) rearranged homodrimanes $-\mathrm{C}_{16} \mathrm{H}_{30}$ hexamethyldecahydronaphthalenes, (10)-8 $8(\mathrm{H})$ homodrimane $-\mathrm{C}_{16} \mathrm{H}_{30}$; column (B) $-n$-alkylbenzenes - number on the peak describes the number of carbon atoms in the $n$-alkylbenzene homologue; column (C)-C1-C3-naphthalenes: assignment of all polyalkylnaphthalene peaks is shown in Fig. 17

Mostno-2, and Cychry-2 wells) the concentration of one homologue with 15 carbon atoms in the chain of the $n$-alkane substituent ( $n$-pentadecylbenzene, $\mathrm{C}_{21}$ ) exhibits a 
pronounced elevation as compared to the neighboring counterparts. Furthermore, a gradual decrease of the observed $\mathrm{C}_{21} n$-alkylbenzene elevation (peak ' 21 ' on $n$-alkylbenzene mass chromatogram profile in Fig. 16, column (B)), similar to the earlier observed shift in $8 \beta(\mathrm{H})$-drimane and $8 \beta(\mathrm{H})$ homodrimane concentration, follows-up the wells location path from NE to SW paralleling the general direction of hydrocarbon migration. The prevalence of $n$ - $\mathrm{C}_{15}$-benzene may be associated with a specific precursor contributing to the source of OM for group II oils during deposition. The elevation of the $n$-pentadecylbenzene concentration in the $n$-alkylbenzene composition in one of the oil group only confirms the separation of the analyzed oils into two groups.

Studies on methylnaphthalenes in oils have shown the usefulness of this compound class for evaluating the source of OM, and source rock maturity and its lithology (Radke 1988; Budzinski et al. 1995; Van Aarssen et al. 1999; Huang and Pearson 1999; Asahina and Suzuki 2016, 2018). For the analyzed oils, the composition of $\mathrm{C} 1-\mathrm{C} 3$-naphthalenes is illustrated in Fig. 16 column (C). The observed compositional differences additionally support the differentiation of the oils into two groups what is consistent with the oils' assignment to the groups on the basis of variations in sesquiterpane and $n$-alkylbenzene compositions. Detailed assignment of mass chromatographic peaks to the respective $\mathrm{C} 0-\mathrm{C} 3$-naphthalene structures, exemplified for oil from the Zielin-2 well is shown in Fig. 17. In the dimethylnaphthalene isomers of group II, there is a distinctive elevation in 1,6-dimethylnaphthalene relative to the nearest peak of 1,3-+1,7-dimethylnaphthalenes (peak marked in the Fig. 16 column (C) by asterisk). This feature with elevated relative concentration of 1,6-dimethylnaphthalene in C2-naphthalenes composition may result from both thermal decomposition of cadinene or polycadinenes at an advanced stage of maturity or be caused by the presence of clay mineral constituents in the source rock mineral matrix (Asahina and Suzuki 2016, 2018). It should be mentioned that consideration of the presence of polycadinanes in $\mathrm{Ca} 2$ strata is justified since they were observed in Permian coals (Peters et al. 2005), suggesting that they are not restricted to an angiosperm origin. However, the lack of cadinane and cadalene respectively in sesquiterpanes and $\mathrm{C}_{5}$-naphthalene compositions of the analyzed oils excludes polycadinenes as a source for 1,6-dimethylnaphthalene. In contrast, prominent relative abundances of 1,6-dimethylnaphthalene are not observed in the oils of group I. Furthermore, the overall alkylation level of C1-C3-naphthalenes in oils of group I is markedly higher compared to the oils of group II. It is clearly noticeable by comparing the polyalkylnaphthalene composition in selected oils of similar maturity from the respective oil groups. For instance, the $\mathrm{C} 1-\mathrm{C} 3$-naphthalenes profile in the Namyślin-1 oil (representative of group I, $\mathrm{VR}_{\mathrm{c}}$ is $0.84 \%$ ) C2- and C3-naphthalenes have a much higher abundance in relation to C1-naphthalenes than in the Cychry-2 oil (oil maturity equivalent of group II, $\mathrm{VR}_{\mathrm{c}}$ is $0.73 \%$ ). It has been recognized that for a given maturity of deposited organic matter in a carbonate matrix preserved polyalkylated $\mathrm{PAH}$ structures have a higher degree of alkylation as compared to their alkylation in siliciclastic rocks (Requejo et al. 1996). Thus, the observed higher C1-C3-naphthalene alkylation

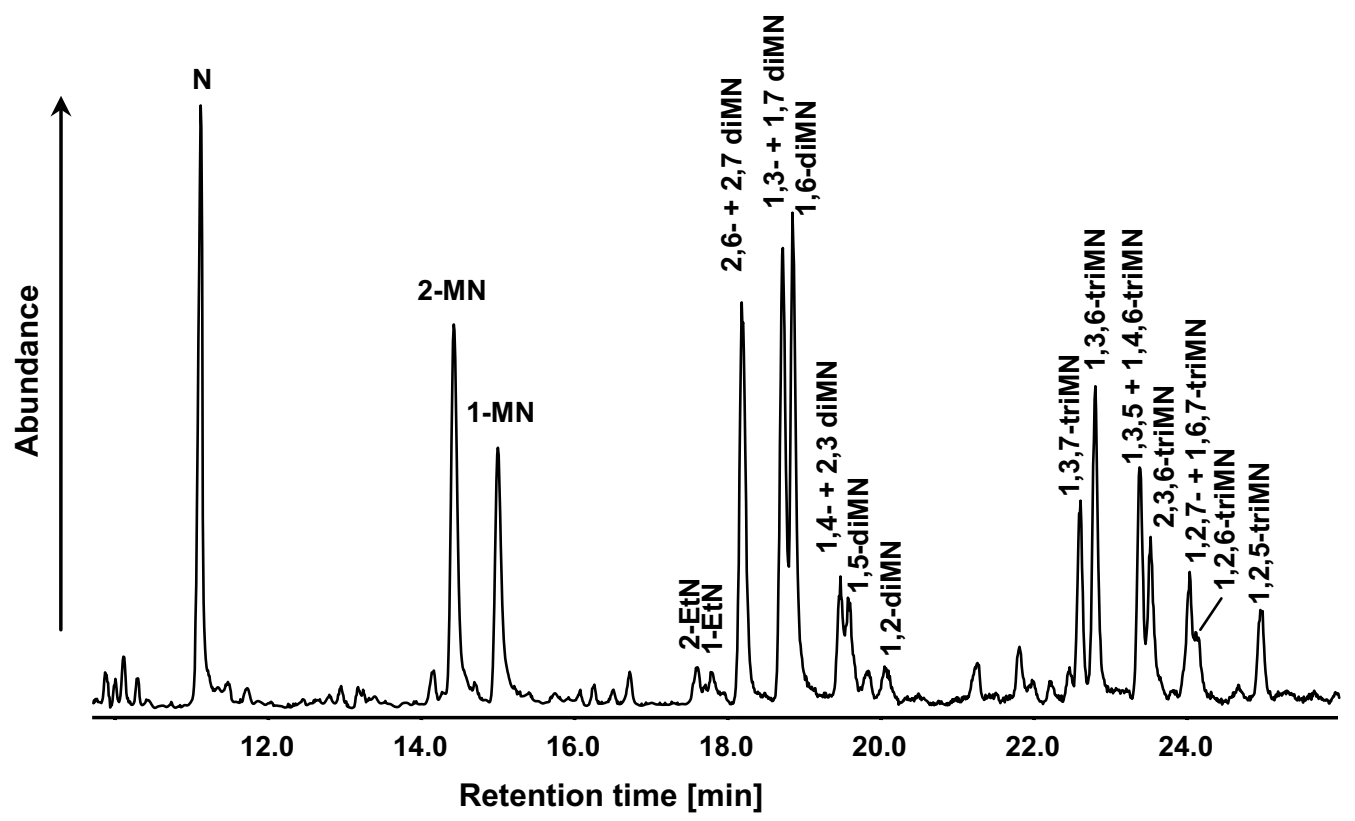

Fig. 17 Homologous distribution of naphthalene and C0-C3-naphthalenes in crude oil from the Zielin-2 well 
and lack of elevated 1,6-dimethylnaphthalene concentration in the oils of group I indicate a carbonate source rock while lower naphthalene alkylation and an elevated 1,6-dimenthylnaphthalene concentration in the oils of group II is associated with the presence of clay minerals in their source rocks; this was confirmed by the earlier findings within BMB and Cychry platforms by Kotarba and Wagner (2007) and Kosakowski and Krajewski (2015).

Since the source rocks for the oils of group I (= group VI in Słowakiewicz et al. 2018) have not been confirmed, and taking into account the diverse specificity in their molecular composition of selected compound classes compared to that in the oils of group II, together with the increasing maturity direction of the hydrocarbons and the known Zechstein subsidence in that NE direction (Hakenberg and Świderska 1997; Czekański et al. 2010), it is postulated that the hydrocarbons which accumulated in the Zielin isolated carbonate platform migrated even further from that NE direction, from carbonates in the wider basin of the Gorzów Block, towards the SW direction. Most probably, the oils were sourced from organic-rich facies of the platform top (lagoonal-microbial-tidal flat) and they migrated laterally through the strata following subsidence and tilting of the platform in this part of the Main Dolomite basin, in a similar way to that suggested by Kotarba and Wagner (2007) for the Gorzów-Międzychód-Lubiatów area.

\section{Conclusions}

The Zielin isolated carbonate platform located in the eastern part of the SPB (western Poland) was formed on a partially eroded paleovolcanic cone. It was partially covered by Rotliegend sediments and further by $\mathrm{Ca} 1$ carbonates and $\mathrm{A} 1$ evaporites. Above the $\mathrm{Z} 1$ anhydrites were developed $\mathrm{Ca} 2$ carbonate rocks consisting of a diverse lithofacies pattern wherein reservoirs for hydrocarbons occur in the Zielin oilfield. Carbonate deposition took place under shallow penesaline, sulphate-poor conditions. It is characterized by good petrophysical properties in some intervals with well-developed pore networks up to $20 \%$ porosity and permeability up to $6600 \mathrm{mD}$.

3D seismic data, sedimentological and microfacies observations show that Late Rotliegend events significantly influenced the development of the Zielin evaporite-carbonate platform. Post-orogenic vertical movements of the Variscan basement had a large impact on the Zielin paleohigh and $\mathrm{Ca} 2$ thickness.

The $\mathrm{Ca} 2$ rocks from the Zielin-1, -2 , and $3 \mathrm{~KB}$ is wells are very low in TOC content, from commonly being lean or containing trace amounts to locally $0.3 \%$. Thus, minor carbonate source rocks deposited in situ had no hydrocarbon potential. The main source of hydrocarbons trapped in the
Zielin atoll is type II kerogen of algal origin. The maturity of the hydrocarbons extracted from Zielin $\mathrm{Ca} 2$ rocks assessed from MPI- 1 is within the range from 0.78 to $0.85 \%$ in mean vitrinite reflectance, whereas for the Zielin-2 and -3Kbis oils it is little higher i.e. 0.90 and $0.82 \%$, respectively. This range is consistent with the optical and stereochemical equilibria of steranes and pentacyclic triterpanes present in the $\mathrm{Ca} 2$ rock from the Zielin-3KBis well, depth $3229.5 \mathrm{~m}$.

The maturity of the oils derived from the wells surrounding the Zielin atoll and their differentiation on the basis of molecular specificity of sesquiterpanes, $n$-alkylbenzenes and polyalkylnaphthalenes indicate that the hydrocarbons accumulated in the Zielin isolated carbonate platform have migrated along a general NE-SW pathway from Różańsko-4 well through the Zielin wells to Namyślin-1 well.

Acknowledgements The study has been partly supported by the Ministry of Science and Higher Education of Poland (Project no 61.5105.0802.00.0 awarded to M. Słowakiewicz). The authors are thanked to Geofizyka Toruń SA and Polish Oil and Gas Company (PGNiG SA) for providing materials and permission to publish and to Paweł Kosakowski, Dariusz Więcław, Maurice Tucker, Hubert Kiersnowski, and an anonymous reviewer whose comments and recommendations have significantly raised scientific value of the manuscript. We express our special gratitude to the deceased Cezary Grelowski $(\dagger)$, for initiating the research and combining action, which made the publication a reality.

Open Access This article is distributed under the terms of the Creative Commons Attribution 4.0 International License (http://creativeco mmons.org/licenses/by/4.0/), which permits unrestricted use, distribution, and reproduction in any medium, provided you give appropriate credit to the original author(s) and the source, provide a link to the Creative Commons license, and indicate if changes were made.

\section{References}

Asahina K, Suzuki N (2016) Alkyl naphthalenes and tetralins as indicators of source and source rock lithology_pyrolysis of a cadinenetype sesquiterpene in the presence and absence of montmorillonite. J Petrol Sci Eng 145:657-667

Asahina K, Suzuki N (2018) Methylated naphthalenes as indicators for evaluating the source and source rock lithology of degraded oils. Org Geochem 124:46-62

Barker CE, Pawlewicz MJ (1994) Calculation of vitrinite reflectance from thermal histories and peak temperatures. In: Murkhopadhyay PK, Dow WG (eds) Vitrinite reflectance as a maturity parameter. Applications and limitations. ACS Symposium Series 570, pp 216-229

Behar F, Beaumont V, Penteado HL, De B (2001) Rock-Eval 6 technology: performances and developments. Oil Gas Sci Technol 56(2):111-134

Belopolsky A, Droxler AW (2003) Imaging tertiary carbonate system-the Maldives, Indian Ocean: insights into carbonate sequence interpretation. Lead Edge 22(7):646-652

Bosence D (2005) A genetic classification of carbonate platforms based on their basinal and tectonic settings in the Cenozoic. Sed Geol 175(1-4):49-72 
Breitkreuz C, Geißler M, Schneider J, Kiersnowski H (2008) Basin initiation: volcanism and sedimentation. In: Littke R, Bayer U, Gajewski D, Nelskamp S (eds) Dynamics of complex intracontinental basins. The Central European Basin system. Springer, Berlin, pp 173-180

Budzinski H, Garrigues P, Connan J, Devillers J, Domine D, Radke M, Oudin JL (1995) Alkylated phenanthrene distributions as maturity and origin indicators in crude oils and rock extracts. Geochim Cosmochim Acta 59(10):2043-2056

Burgess PM, Winefield P, Minzoni M, Elders C (2013) Methods for identification of isolated carbonate buildups from seismic reflection data. AAPG Bull 97(7):1071-1098

Czekański E, Kwolek K, Mikołajewski Z (2010) Złoża węglowodorów w utworach cechsztyńskiego dolomitu głównego (Ca2) na bloku Gorzowa. Przegląd Geologiczny 58(8):695-703

Espitalié J, Laporte JL, Madec F, Marqius J, Leplat P, Paulet J, Boutelau A (1977) Méthode rapide de caractérisation des roches mères de leur potentiel pétrolier et de leur degré d'évolution. Revue de'l Institut Français du Pétrole 33(1):23-42

Fowler M, Snowdon L, Stasiuk V (2005) Applying petroleum geochemistry to hydrocarbon exploration and exploitation. AAPG Short Course Notes, Calgary, p 224

Geißler M, Breitkreuz C, Kiersnowski H (2008) Late Paleozoic volcanism in the central part of the Southern Permian Basin (NE Germany, W Poland), facies distribution and volcano-topographic hiati. Int J Earth Sci 97(5):973-989

Groetsch J, Mercandier C (1999) Integrated 3-D reservoir modelling based on 3-D seismic: the Tertiary Malampaya and Camago buildups, offshore Palawan, Philippines. AAPG Bull 83(11):1703-1728

Hakenberg M, Świderska J (1997) Propagation of the south-eastern segment of the Polish Trouhg connected with bounding fault zones (from Permian to the Late Jurassic). Comptes Rendus de l'Académie des Sciences Series IIA Earth Planet Sci 324(10):793-803

Hartgers WA, Sinninghe Damsté JS, De Leeuw JW (1994) Geochemical significance of alkylbenzene distributions in flash pyrolysates of kerogens, coals, and asphaltenes. Geochim Cosmochim Acta 58(7):1759-1775

Huang HP, Pearson MJ (1999) Source rock palaeoenvironments and controls on the distribution of dibenzothiophenes in lacustrine crude oils, Bohai Bay Basin, eastern China. Org Geochem 30(11):1455-1470

Hughes WB, Holba AG, Dyou LIP (1995) The ratios of dibenzothiophene to phenanthrene and pristane to phytane as indicators of depositional environment and lithology of petroleum source rocks. Geochim Cosmochim Acta 59(17):3581-3598

Kiersnowski H, Peryt TM, Buniak A, Mikołajewski Z (2010) From the intra-desert ridges to the marine carbonate island chain: middle to late Permian (Upper Rotliegend-Lower Zechstein) of the Wolsztyn-Pogorzela high, west Poland. Geol J 44(2-3):319-335

Kosakowski P, Krajewski M (2014) Hydrocarbon potential of the Zechstein Main Dolomite in the western part of the Wielkopolska platform, SW Poland: new sedimentological and geochemical data. Mar Pet Geol 49:99-120

Kosakowski P, Krajewski M (2015) Hydrocarbon potential of the Zechstein Main Dolomite (Upper Permian) in western Poland: relation to organic matter and facies characteristics. Marine Petrol Geol 68(Part A):675-694

Kotarba M, Wagner R (2007) Generation potential of the Zechstein Main Dolomite ( $\mathrm{Ca} 2)$ carbonates in the Gorzów Wielkopolski-Międzychód-Lubiatów area. Geological and geochemical approach to microbial-algal source rock. Przegląd Geologiczny 12/1:1025-1036

Kotarba MJ, Więcław W, Stecko Z (2000) Skład, geneza i środowisko generowania gazu ziemnego w utworach dolomitu głównego zachodniej częścu obszaru przedsudeckiego. Przegląd Geologiczny 48(5):429-435

Kwolek K, Mikołajewski Z (2010) Kryteria identyfikacji obiektów litofacjalnych jako potencjalnych pułapek złożowych w utworach dolomite głównego (Ca2) u podnóża platform I mikroplatform węglanowych w środkowo-zachodniej Polsce. Przegląd Geologiczny 58(5):426-435

Lafargue E, Espitalié J, Marqius J, Pillot D (1998) Rock-Eval application in hydrocarbon exploration, production and soil contamination studies. Revue de l'Institut Francais du Petrole 53(4):421-437

Maliszewska A, Kiersnowski H, Jackowicz E (2003) Wulkanoklastyczne osady czerwonego spagowca dolnego na obszarze Wielkpolski. Prace Państwowego Instytutu Geologicznego 179:1-59

Maliszewska A, Jackowicz E, Kuberska M, Kiersnowski H (2016) Skały permu dolnego (czerwonego spagowca) zachodniej Polski-monografia petrograficzna. Prace Państwowego Instytutu Geologicznego 204:1-115

Mamczur R, Radecki S, Wojtkowiak Z (1997) O największym złożu ropy naftowej w Polsce Barnówko-Mostno-Buszewo (BMB). Przegląd Geologiczny 45(6):582-588

Marriott RA, Pirzadeh P, Marrugo-Hernandez JJ, Raval S (2016) Hydrogen sulfide formation in oil and gas. Can J Chem 94(4):406-413

Moldowan MJ, Fago RJ, Carlson RMK, Young DC, Vanduyne G, Clardy M, Schoell J, Pillinger CT, Watt DS (1991) Rearranged hopanes in sediments and petroleum. Geochim Cosmochim Acta 55(11):3333-3353

Narkiewicz M, Dadlez R (2008) Geologiczna regionalizacja Polskizasady ogólne i schemat podziału w planie podkenozoicznym i podpermskim. Przegląd Geologiczny 56(5):391-397

Noble RA, Alexander R, Kagi RJ (1987) Configurational isomerization in sedimentary bicyclic alkanes. Org Geochem 11(3):151-156

Oświęcimska A, Protas A (1995) The non-typical gas oil "pinnacle" reservoir in Main Dolomite in Poland. Conference and Exhibition. Modern Exploration and Improved Oil and Gas Recovery Methods. Cracow, 12-15 September, pp 270-271

Paumard V, Zuckmeyer E, Boichard R, Jorry SJ, Bourget J, Borgomano J, Maurin T, Ferry J-N (2017) Evolution of Late OligoceneEarly Miocene attached and isolated carbonate platforms in a volcanic ridge context (Maldives type), Yadana field, offshore Myanmar. Mar Pet Geol 81:361-387

Pedentchouk N, Freeman KH, Harris NB, Clifford DJ, Grice K (2004) Sources of alkylbenzenes in lower cretaceous lacustrine source rocks, West African rift basins. Org Geochem 35(1):33-45

Peryt TM (1986) The Zechstein (Upper Permian) Main Dolomite deposits of the Leba elevation, northern Poland: facies and depositional history. Facies 14(1):151-200

Peryt TM (1994) The anatomy of a sulphate platform and adjacent basin system in the Łeba sub-basin of the Lower Werra Anhydrite (Zechstein, Upper Permian), northern Poland. Sedimentology 41(1):83-113

Peryt TM, Dyjaczyński K (1991) An isolated carbonate bank in the Zechstein Main Dolomite Basin. Western Poland. J Pet Geol 14(4):445-458

Peters KE (1986) Guidelines for evaluating petroleum source rock using programmed pyrolysis. AAPG Bull 70(3):318-329

Peters KE, Cassa MR (1994) Applied source rock geochemistry. AAPG Memoir 60:93-117

Peters KE, Walters CC, Moldowan JM (2005) The biomarker Guide. Biomarkers and isotopes in petroleum exploration and earth history, vol 2. Cambridge University Press, Cambridge, p 613

Posamentier HW, Laurin P, Warmath A, Purnama M, Drajat D (2010) Seismic stratigraphy and geomorphology of Oligocene to Miocene carbonate buildups offshore Madura, Indonesia. SEPM Spec Publ 95:175-194 
Radke M (1988) Application of aromatic compounds as maturity indicators in source rocks and crude oil. Mar Pet Geol 5(3):224-236

Radke M, Welte DH, Willsch H (1986) Maturity parameters based on aromatic hydrocarbons: influence of the organic matter type. Org Geochem 10(1-3):51-63

Rank-Friend M, Elders FC (2004) The evolution and growth of Central Graben salt structures. Salt Dome Province. Danish North Sea. Geol Soc Lond Mem 29:149-163

Reijers TJA (2012) Sedimentology and diagenesis as, hydrocarbon exploration tools 'in the Late Permian Zechstein-2 Carbonate Member (NE Netherlands). Geologos 18(3):163-195

Requejo AG, Sassen R, Mcdonald T, Denoux G, Kennicutt MC II, Brooks JM (1996) Polynuclear aromatic hydrocarbons (PAH) as indicators of the source and maturity of marine crude oils. Org Geochem 24(10-11):1017-1033

Schoenherr J, Littke R, Urai JL, Kukla PA, Rawahim Z (2007) Polyphase thermal evolution in the Infra-Cambrian Ara Group (South Oman Salt Basin) as deduced by maturity of solid reservoir bitumen. Org Geochem 38(8):1293-1318

Shanmugam G (1985) Significance of coniferous rain forests and related organic matter in generating commercial quantities of oil, Gippsland Basin, Australia. AAPG Bull 69(8):1241-1254

Sinninghe Damsté JS, Kock-Van Dalen AC, Albrecht PA, de Leeuw JW (1991) Identification of long-chain 1,2-di-normal-alkylbenzenes in Amposta crude oil from the Tarragona basin, Spanish Mediterranean-implications for the origin and fate of alkylbenzenes. Geochim Cosmochim Acta 55(4):3677-3683

Sinninghe Damsté JS, Keely BJ, Betts S, Baas M, Maxwell JR, de Leeuw JW (1993) Variations in abundances and distributions of isoprenoid chromans and long-chain alkylbenzenes in sediments of the Mulhouse Basin: a molecular sedimentary record of palaeosalinity. Org Geochem 20(8):1201-1215

Slowakiewicz M, Mikolajewski Z (2009) Sequence stratigraphy of the Upper Permian Zechstein Main Dolomite carbonates in western Poland: a new approach. J Pet Geol 32(3):215-234

Słowakiewicz M, Tucker ME, Perri E, Pancost RD (2015) Nearshore euxinia in the photic zone of an ancient sea. Palaeogeogr Palaeoclimatol Palaeoecol 426:242-259

Słowakiewicz M, Tucker ME, Hindenberg K, Mawson M, Idiz EF, Pancost RD (2016) Nearshore euxinia in the photic zone of an ancient sea: part II-the bigger picture and implications for understanding ocean anoxia. Palaeogeogr Palaeoclimatol Palaeoecol 461:432-448

Słowakiewicz M, Blumenberg M, Więcław D, Rőhling H-G, Scheeder G, Hindenberg K, Leśniak A, Idiz EF, Tucker ME, Pancost RD, Kotarba MJ, Gerling JP (2018) Zechstein Main Dolomite oil characteristics in the Southern Permian Basin: I. Polish and German sectors. Mar Pet Geol 93:356-375

Stewart SA (2006) Implications of passive salt diapir kinematics for reservoir segmentation by radial and concentric faults. Mar Pet Geol 23:843-853

Strohmenger C, Voigt E, Zimdars J (1993) Einflu $\beta$ von Eustasie und Paläorelief auf die sedimentologische und diagenetische Entwicklung der Zechstein 2 Karbonate (Ober-Perm, NordostDeutschland). Erdöl Erdgas Kohle 109:445-450

Taylor GH, Teichmúller M, Davis A, Diessel CFK, Littke R, Robert P (1998) Organic petrology. Gebrüder Borntraeger, Berlin, p 704

Tucker ME, Wright VP (1990) Carbonate sedimentology. Blackwell Science Ltd, Hoboken, p 496

Van Aarssen BGK, Bastow TP, Alexander R, Kagi RI (1999) Distributions of methylated naphthalenes in crude oils: indicators of maturity, biodegradation and mixing. Org Geochem 30(10):1213-1227

Volkman JK (1988) Biological marker compounds as indicators of the depositional environments of petroleum source rocks. Geol Soc Lond Spec Publ 40:103-122

Wagner R (2012) Mapa paleogeograficzna dolomitu głównego (Ca2) w Polsce. Narodowe Archiwum Geologiczne PIG-PIB, Warszawa

Weston RJ, Philp RP, Sheppard CM, Woolhouse AN (1989) Sesquiterpanes, diterpanes and other higher terpanes in oils from the Taranaki basin of New Zealand. Org Geochem 14(4):405-421

Wright VP, Burchette TP (1996) Shallow-water carbonate environments. In: Reading HG (ed) Sedimentary environments: processes, facies and stratigraphy. Blackwell Scientific Publications, Oxford, pp 325-394

Zhang S, Huang H, Su J, Liu M, Zhang H (2014) Geochemistry of alkylbenzenes in the Paleozoic oils from the Tarim Basin, NW China. Org Geochem 77:126-139 